\title{
Role of quinolones and quinoxaline derivatives in the advancement of treatment of tuberculosis
}

\author{
Mohammad Asif \\ Department of Pharmacy, GRD (PG) IMT, Dehradun, 248009 Uttarakhand, India \\ E-mail: aasif321@gmail.com
}

Copyright $\odot 2015$ Mohammad Asif. This is an open access article distributed under the Creative Commons Attribution License, which permits unrestricted use, distribution, and reproduction in any medium, provided the original work is properly cited.

\begin{abstract}
The need of new chemotherapeutic drugs to improve tuberculosis control and treatment particularly against multidrugresistant (MDR) and extensively drug resistant (XDR) strains of Mycobacterium. The atitubercular drugs are used in current chemotherapy have different chemical moieties. In this review, we provide an overview of the quinolone drugs as an antitubercular drug. Generally quinolone drugs are mainly used against many gram-positive and gram-negative bacterial infections including resistance strains also. Various quinolones are being used to control and treatment of tubercular infections including MDR, XDR and atypical Mycobacterium strains. Fluoroquinolones are an important quinolones, especially for strains that are resistant to first-line agents.
\end{abstract}

Keywords: Chemotherapeutic Agents; Multidrug-Resistant; Extensively Drug Resistant; Tuberculosis; Quinolones.

\section{Introduction}

The first quinolone, nalidixic acid, was isolated as a by-product of the synthesis of chloroquine and has been used for the treatment of urinary tract infections (UTIs). The fluorinated 4-quinolones, such as ciprofloxacin, moxifloxacin, and gatifloxacin have important therapeutic effects. These agents have broad antimicrobial activity against wide variety of infectious diseases. These compounds have relatively few side effects and microbial resistance to their action does not develop rapidly [1], [2]. Rare and potentially fatal side effects, however, have resulted in the withdrawal from the market of temafloxacin (hemolytic anemia), trovafloxacin (hepatotoxicity), grepafloxacin (cardiotoxicity), and clinafloxacin (phototoxicity) [3]. The narrow antibacterial spectrum of nalidixic acid was first expanded through drugs such as norfloxacin, pefloxacin, ofloxacin and ciprofloxacin to improve the utility for treating gram-negative bacterial infections. These were followed by drugs e.g. temafloxacin, sparfloxacin, grepafloxacin and gatifloxacin, which, whilst maintaining gram-negative activity, had additional effects on gram-positive microbes. More recently the bacterial profile of the quinolones has been enlarged again by such drugs as clinafloxacin, trovafloxacin, gemifloxacin and moxifloxacin to encompass anaerobic bacteria. In general these drugs are well tolerated [4] but, in some cases, side effects have been sufficiently severe to cause withdrawal from the market [grepafloxacin (cardiotoxicity); trovafloxacin (hepatotoxicity)]. In line with the expanding indications for the quinolones, a number of these compounds have shown promise for the treatment of mycobacterial infections. Ciprofloxacin and ofloxacin are currently finding utility as second-line or alternative TB drugs. However, resistance to these drugs develops quickly when used as single agent treatments or as add-ons to other drugs which are already failing [5]. Consequently, in seeking to evaluate the potential of the latest generation of quinolones as TB treatments, the issue of cross resistance to the existing drugs needs to be addressed- possibly by pursuing compounds inherently more bactericidal than ofloxacin and ciprofloxacin. A further advance would be to select quinolones with increased half-lives to facilitate once daily dosing.

Nalidixic acid, the first antibacterial quinolone, was introduced in 1963. It is not fluorinated and is excreted too rapidly to be useful for systemic infections. Oxolinic acid and cinoxacin are similar in structure and function to nalidixic acid. Their mechanism of action is the same as that of the fluoroquinolones (FQs). These agents were useful only for the treatment of UTIs and are rarely used now, having been made obsolete by the more efficacious fluorinated quinolones. 
The important quinolones are synthetic fluorinated analogs of nalidixic acid. They are active against a variety of grampositive and gram-negative bacteria. Quinolones block bacterial DNA synthesis by inhibiting bacterial topoisomerase-II (DNA gyrase) and topoisomerase IV. Inhibition of DNA gyrase prevents the relaxation of positively supercoiled DNA that is required for normal transcription and replication. Inhibition of topoisomerase-IV interferes with separation of replicated chromosomal DNA into the respective daughter cells during cell division [6,7]. Fluorinated derivatives (ciprofloxacin, levofloxacin, etc), have greatly improved antibacterial activity. Some quinolones such as ciprofloxacin and levofloxacin inhibit strains of MMtb at concentrations less than $2 \mathrm{~g} / \mathrm{mL}$. They are also active against atypical mycobacteria. Ofloxacin was used in the past, but levofloxacin is preferred because it is the L-isomer of ofloxacin (racemic mixture). Levofloxacin tends to be slightly more active in vitro than ciprofloxacin against Mtb; ciprofloxacin is slightly more active against atypical mycobacteria. Serum concentrations of $2-4 \mathrm{~g} / \mathrm{mL}$ and $4-8 \mathrm{~g} / \mathrm{mL}$ are achieved with standard oral doses of ciprofloxacin and levofloxacin, respectively. The FQs are important drugs for TB, especially for strains that are resistant to first-line agents. Resistance, which may result from any one of several single point mutations in the gyrase A subunit, develops rapidly if a FQ is used as a single agent; thus, the drug must be used in combination with two or more other active agents [8-10]. Several newer quinolones have improved activity against gram-positive cocci. Methicillin-susceptible strains of S. aureus are generally susceptible to these FQs, but methicillinresistant strains of staphylococci are often resistant. Streptococci and enterococci tend to be less susceptible than staphylococci, and efficacy in infections caused by these organisms is limited. Ciprofloxacin is the most active agent of this group against gram negatives, $\mathrm{P}$ aeruginosa in particular. Levofloxacin, the L-isomer of ofloxacin and twice as potent, has superior activity against gram-positive organisms, including $\mathrm{S}$ pneumoniae. Gatifloxacin, moxifloxacin, sparfloxacin, and trovafloxacin comprise a third group of FQs with improved activity against gram-positive organisms, particularly S pneumoniae and to some extent staphylococci. The FQs also are active against agents of atypical pneumonia (eg, mycoplasmas and chlamydiae) and against intracellular pathogens such as legionella species and some mycobacteria, including Mtb and $\mathrm{M}$ avium complex. Moxifloxacin and trovafloxacin, in addition to enhanced gram positive activity, also have good activity which other FQs lack against anaerobic bacteria [11-16].

The FQs are highly active against Mtb as well as nontuberculous mycobacteria (NTM) and are important components of treatment regimens of MDR-TB [17]. The C-8-methoxy-fluoroquinolones, such as gatifloxacin and moxifloxacin, are the most active and therefore least likely to result in the development of quinolone resistance. Unfortunately, when resistance develops to one FQ in mycobacteria, cross-resistance develops within this entire class of antibiotics. Thus the most active FQs should be used, and only in combination with other anti-TB agents, to prevent resistance from developing [18]. The quinolones (e.g., ciprofloxacin, levofloxacin, moxifloxacin, and gatifloxacin) drugs have inhibitory activity against MAC bacteria in vitro (at concentrations of $\leq 100 \mu \mathrm{g} / \mathrm{ml}$ ). Minimal inhibitory concentrations (MIC) for M. fortuitum and M. kansasii are $\leq 3 \mu \mathrm{g} / \mathrm{ml}$ for these quinolones but M. chelonae usually are resistant. Singleagent therapy of $M$. fortuitum infection with ciprofloxacin has been associated with the development of resistance. Ciprofloxacin has been used as part of a 4-drug regimen (with clarithromycin, rifabutin, and amikacin) as salvage therapy for M. avium Complex (MAC) infections in HIV-infected patients, with improvement in symptoms [19]. MDRTB has been treated with ofloxacin, in combination with second-line agents. Moxifloxacin and gatifloxacin are more active in vitro than the older FQs and would be expected to be useful agents clinically.

\subsection{Mechanism of action}

The quinolones target bacterial DNA gyrase and topoisomerase IV [17]. For many gram-positive bacteria (such as S. aureus), topoisomerase IV is the primary activity inhibited by the quinolones. In contrast, for many gram-negative bacteria (such as E. coli), DNA gyrase is the primary quinolone target [20], [21]. The individual strands of doublehelical DNA must be separated to permit DNA replication or transcription. The bacterial enzyme DNA gyrase is responsible for the continuous introduction of negative supercoils into DNA. This is an ATP-dependent reaction requiring that both strands of the DNA be cut to permit passage of a segment of DNA through the break; the break then is resealed. The DNA gyrase of E. coli is composed of two 105,000-dalton a subunits and two 95,000-dalton B subunits encoded by the gyrA and gyrB genes, respectively. The A subunits, which carry out the strand-cutting function of the gyrase, are the site of action of the quinolones. The drugs inhibit gyrase-mediated DNA supercoiling at concentrations that correlate well with those required to inhibit bacterial growth $(0.1$ to $10 \mathrm{mg} / \mathrm{ml})$. Mutations of the gene that encodes the A subunit polypeptide can confer resistance to these drugs (Hooper, 2000a). Topoisomerase IV also is composed of four subunits encoded by the parC and parE genes in E. coli [2], [17]. Topoisomerase IV separates interlinked (catenated) daughter DNA molecules that are the product of DNA replication. Eukaryotic cells do not contain DNA gyrase. However, they do contain a conceptually and mechanistically similar type II DNA topoisomerase that removes positive supercoils from eukaryotic DNA to prevent its tangling during replication. This enzyme is the target for some antineoplastic agents. Quinolones inhibit eukaryotic type II topoisomerase only at much higher concentrations (100 to $1000 \mathrm{mg} / \mathrm{ml})[22]$. 


\subsection{Antibacterial spectrum}

The fluoroquinolones are potent bactericidal agents against E. coli and various species of Salmonella, Shigella, Enterobacter, Campylobacter, and Neisseria [23]. MIC of the FQs for 90\% of these strains (MIC90) usually are less than $0.2 \mathrm{mg} / \mathrm{ml}$. Ciprofloxacin is more active than norfloxacin against P. aeruginosa; values of MIC90 range from 0.5 to $6 \mathrm{mg} / \mathrm{ml}$. The FQs also have good activity against staphylococci, but not against methicillin-resistant strains $($ MIC90 = 0.1 to $2 \mathrm{mg} / \mathrm{ml}$ ). Activity against streptococci is limited to a subset of the quinolones, including levofloxacin, gatifloxacin, and moxifloxacin [2], [23]. Several intracellular bacteria are inhibited by fluoroquinolones; these include species of Chlamydia, Mycoplasma, Legionella, Brucella, and Mycobacterium [6], [24]. Ciprofloxacin, ofloxacin, and pefloxacin have MIC90 values from 0.5 to $3 \mathrm{mg} / \mathrm{ml}$ for M. fortuitum, M. kansasii, and Mtb; ofloxacin and pefloxacin are active in animal models of leprosy [2]. Several FQs have activity against anaerobic bacteria, including garenoxacin and gemifloxacin [25]. Resistance to quinolones may develop during therapy via mutations in the bacterial chromosomal genes encoding DNA gyrase or topoisomerase IV or by active transport of the drug out of the bacteria [26], [27]. Resistance has increased after the introduction of fluoroquinolones, especially in Pseudomonas and staphylococci [28], [29]. Increasing FQ resistance also is being observed in C. jejuni, Salmonella, N. gonorrhoeae, and S. pneumoniae [30-33].

\subsection{Therapeutic uses}

Nalidixic acid is useful only for UITs caused by susceptible microorganisms. The FQs are significantly more potent and have a much broader spectrum of antimicrobial activity. The FQs are more efficacious than trimethoprimsulfamethoxazole for the treatment of UTIs and to be effective in those patients who are not responding [20], [34]. Norfloxacin, ciprofloxacin, and ofloxacin all have been effective in the treatment of prostatitis caused by sensitive bacteria [20]. The quinolones are contraindicated in pregnancy. The FQs lack activity for Treponema pallidum but have activity in vitro against N. gonorrhoeae, C. trachomatis, and H. ducreyi. For chlamydial urethritis/cervicitis, ofloxacin or sparfloxacin treatment with doxycycline or a single dose of azithromycin. A single oral dose of a FQ such as ofloxacin or ciprofloxacin is effective treatment for sensitive strains of N. gonorrhoeae, but increasing resistance to FQs has led to ceftriaxone being the first-line agent for this infection [35]. Pelvic inflammatory disease has been treated effectively with ofloxacin combined with an antibiotic with activity against anaerobes (clindamycin or metronidazole) [36]. Chancroid (infection by H. ducreyi) can be treated with ciprofloxacin. For traveler's diarrhea (frequently caused by enterotoxigenic E. coli), the quinolones are equal to trimethoprim-sulfamethoxazole in effectiveness [37], [38]. Norfloxacin is superior to tetracyclines in decreasing the duration of diarrhea in cholera [39]. Ciprofloxacin and ofloxacin treatment cures most patients with enteric fever caused by S. typhi, as well as bacteremic nontyphoidal infections in AIDS patients, and it clears chronic fecal carriage. Shigellosis is treated effectively with either ciprofloxacin or azithromycin [40]. The quinolones should not be used for Shiga toxin-producing E. coli [41]. The major limitation to the use of quinolones for the treatment of community-acquired pneumonia and bronchitis had been the poor in vitro activity of ciprofloxacin, ofloxacin, and norfloxacin against S. pneumoniae and anaerobic bacteria. However, many FQs, including gatifloxacin and moxifloxacin, have excellent activity against S. pneumoniae. Other quinolones also showed activity [42], [43]. The FQs have in vitro activity against respiratory pathogens, including $\mathrm{H}$. influenzae, Moraxella catarrhalis, S. aureus, M. pneumoniae, Chlamydia pneumoniae, and Legionella pneumophila. Either a FQs (ciprofloxacin or levofloxacin) or azithromycin is the antibiotic of choice for L. pneumophila [44]. The FQs have been very effective at eradicating both $\mathrm{H}$. influenzae and $\mathrm{M}$. catarrhalis from sputum. The FQs are used for treatment of community-acquired pneumonia [2]. However, the possibility is a decreasing susceptibility of S. pneumoniae to FQs [45], [46]. The treatment of osteomyelitis requires prolonged antimicrobial therapy with agents active against S. aureus and gram-negative rods [47]. Ciprofloxacin should not be given to children or pregnant women [2]. Failures have been associated with the development of resistance in S. aureus, P. aeruginosa, and Serratia marcescens. In diabetic foot infections, which are commonly caused by a mixture of bacteria including gram-negative rods, anaerobes, streptococci, and staphylococci, the FQs in combination with an agent with antianaerobic activity are a reasonable choice. Ciprofloxacin as sole therapy is effective in 50\% of diabetic foot infections. The prophylaxis of anthrax and has been shown to be effective for the treatment of tularemia [48,49]. The quinolones may be used as part of multiple-drug regimens for the treatment of MDR-TB, atypical mycobacterial infections as well as M. avium complex infections in AIDS.

\subsection{Adverse effects}

Quinolones and fluoroquinolones generally are well tolerated [50]. The common adverse reactions are in GI tract, mostly mild nausea, vomiting, and abdominal discomfort. Diarrhea and antibiotic-associated colitis have been unusual. CNS side effects are predominately mild headache and dizziness. Rarely, hallucinations, delirium, and seizures have occurred, predominantly in patients who also were receiving theophylline or a nonsteroidal antiinflammatory drug. Ciprofloxacin and pefloxacin inhibit the metabolism of theophylline, and toxicity from elevated concentrations of the methylxanthine may occur [51]. Nonsteroidal antiinflammatory drugs may augment displacement of g-aminobutyric 
acid (GABA) from its receptors by the quinolones [52]. Rashes, including photosensitivity reactions, also can occur. Achilles tendon rupture or tendinitis has occurred rarely. Renal disease, hemodialysis, and steroid use may be predisposing factors [50]. All these agents can produce arthropathy in several species of immature animals. Traditionally, the use of quinolones in children has been contraindicated for this reason. However, children with cystic fibrosis given ciprofloxacin, norfloxacin, and nalidixic acid have had few, and reversible, joint symptoms [53]. Therefore, in some cases the benefits may outweigh the risks of quinolone therapy in children. Leukopenia, eosinophilia, and mild elevations in serum transaminases occur rarely. After administration, the quinolones are well absorbed and distributed widely in body fluids and tissues. The FQs are relatively long half-lives of levofloxacin, moxifloxacin, sparfloxacin, and trovafloxacin permit once-daily dosing. Alatrovafloxacin is the inactive, prodrug form of trovafloxacin for parenteral administration. It is rapidly converted to the active compound. Concentrations in prostate, kidney, neutrophils, and macrophages exceed serum concentrations. Most FQs are eliminated by renal mechanisms, either tubular secretion or glomerular filtration. Nonrenally cleared FQs are contraindicated in patients with hepatic failure. The FQs are effective mainly in urinary tract infections even when caused by MDR bacteria, eg, pseudomonas. These agents are also effective for bacterial diarrhea caused by shigella, salmonella, toxigenic E coli, or campylobacter. The FQs (except norfloxacin) have been employed in infections of soft tissues, bones, and joints and in intra-abdominal and respiratory tract infections, including those caused by MDR organisms such as pseudomonas and enterobacter. Ciprofloxacin and ofloxacin are effective for gonococcal infection, including disseminated disease, and ofloxacin is effective for chlamydial urethritis or cervicitis. Ciprofloxacin is a second-line agent for legionellosis. Ciprofloxacin or levofloxacin is occasionally used for treatment of TB and atypical mycobacterial infections. They may be suitable for eradication of meningococci from carriers or for prophylaxis of infection in neutropenic patients. However, levofloxacin, gatifloxacin, and moxifloxacin, with their enhanced gram positive activity and activity against atypical pneumonia agents are likely to be effective and used increasingly for treatment of upper and lower respiratory tract infections. Fluoroquinolones are extremely well tolerated. The most common effects are nausea, vomiting, and diarrhea. Occasionally, headache, dizziness, insomnia, skin rash, or abnormal liver function tests develop. Trovafloxacin has been associated with acute hepatitis and hepatic failure, which has led to its restricted indications. Photosensitivity has been reported with lomefloxacin and pefloxacin. Ideally, these agents should be avoided or used with caution in patients Gatifloxacin has been associated with hyperglycemia in diabetic patients and with hypoglycemia in patients also receiving oral hypoglycemic agents. The FQs may damage growing cartilage and cause an arthropathy. Thus, they are not routinely recommended for use in patients under 18 years of age [54].

\section{Chemotherapy of tuberculosis}

Chemotherapy of TB is mainly depends on first-line anti-TB drugs, which include streptomycin (SM), isoniazid (INH), rifampicin (RIF), ethambutol (EMB) and pyrazinamide (PZA), they more effective and less toxic as compare to secondline anti-TB drugs. Six class of second line drugs that are used in the treatment of TB [54]. A drug may be classified as a second-line because of one of two possible reasons: it may be less effective than the first-line drugs or it may have toxic side-effects or. These comprise of different classes namely, aminoglycosides (amikacin, kanamycin), polypeptides (capreomycin, viomycin), fluoroquinolones (ciprofloxacin, moxifloxacin, etc), thioamides: (ethionamides, prothioamide), cycloserine and p-aminosalicylic acid [54], [55]. Fluoroquinolones such as ciprofloxacin, ofloxacin and moxifloxacin are second line drugs used in combination with first line drugs to treat MDR-TB. The MICs of these FQs are range from 0.12 to $2 \mu \mathrm{g} / \mathrm{mL}$. Levofloxacin, levoisomer of ofloxacin is twice as active as the parent drug. They cause side effects as gastrointestinal reactions, central nervous system disturbances, and skin reactions. While, gatifloxacin and moxifloxacin are new FQ DNA gyrase inhibitors that offer advantages over ofloxacin and ciprofloxacin. These new FQs moxifloxacin and gatifloxacin, are the most advanced anti-TB compounds in clinical development showing promise to be the first new anti-TB drugs in nearly 30 years [56-58].

\section{Need of new antitubercular drugs}

A new TB treatment should offer following three improvements over the existing regimens: shorten the total duration of treatment and/or significantly reduce the number of doses, improve the treatment of MDR-TB and XDR-TB, provide a more effective treatment of latent TB infection [15], [59]. In order to analyse useful to group drug candidates currently in two main categories: 1) Novel chemical entities and 2) Compounds originating from existing families of drugs, where innovative chemistry is used to optimise the compounds. Drug resistance (MDR and XDR) by Mtb is an important obstacle for the treatment and control of TB. The MDR-TB refers to simultaneous resistance to at least two or more of the five first-line anti-TB drugs (INH, RIF, PZA, EMB, and SM). Treatment for MDR-TB is long lasting, less effective, costly, and poorly tolerated [60]. The XDR-TB by definition is resistance to at least INH and RIF in addition to any quinolone and at least one injectable second-line agent (capreomycin, amikacin, and kanamycin). The principles of treatment for MDR-TB and XDR-TB are the same. The main difference is that XDR-TB is associated with a much higher mortality rate than MDR-TB, because of reduced number of effective treatment options [61-63]. Hence there is an urgent need for novel drugs that are active against Mtb in order to shorten the duration of TB therapy [55], [64]. 


\section{Quinolones and fluoroquinolones}

The introduction of nalidixic acid during 1962 has shown the new avenue for the patients with the bacterial infections. The continuous effort to increase the efficacy against bacteraemia has led to identify new prototype quinolone which is active only against gram-negative bacteria similar to that of nalidixic acid. But the introduction of norfloxacin, a FQ derivative during 1980s has changed the landscape of antibacterial chemotherapy being active against both gramnegative and gram-positive bacterial pathogens. Recently, the quinolone drugs; Ofloxacin, Gatifloxacin, Moxifloxacin and Levofloxacin, are serving as second line drugs for TB. In this concern, many researchers optimized the quinolones and evaluated for their anti-TB potency. The FQs were introduced into clinical practice in the 1980s, having broadspectrum antimicrobial activities and widely used for the treatment of bacterial infections. These FQs have been also found to have activity against Mtb [65] and are currently part of the recommended regimen as second-line drugs. Some quinolones (Ciprofloxacin, levofloxacinetc) inhibit strains of Mtb at concentrations less than $2 \mathrm{~g} / \mathrm{mL}$. Indeed, cross-resistance has been reported within the FQ class such that reduced susceptibility to one FQs likely confers reduced susceptibility to all FQs [66], [67]. The major concern is that widespread use of FQs for treatment of other bacterial infections may select for resistant strains of Mtb. The FQs susceptibility is not routinely assessed in clinical isolates of tubercle bacilli, so there is not much information available about the prevalence of FQ resistance in Mtb. They concluded that despite the widespread use of FQs for treatment of common bacterial infection, resistance to FQs remains rare and occurs mainly in MDR-TB strains [68].

In contrast, the incidence of Mtb FQ resistance in a small sample of patients with newly diagnosed TB was found to be high among patients with prior FQ exposure. Cross-resistance was observed among the different FQs tested (ofloxacin, levofloxacin, gatifloxacin, moxifloxacin, and ciprofloxacin) [67]. There are reasons for concerns about the rapid development of resistance particularly when FQs are administered as the only active agent in a failing multi-drug regimen. Moreover, the risk of selecting FQ-resistant Mtb strains by empirically treating with FQs other presumed infections before a diagnosis of TB is established is of great concern. For this reason some investigators in the TB field argue that the use of FQ might be better reserved for specific serious infection. FQs act by inhibiting DNA topoisomerase IV and DNA gyrase, enzymes that control DNA topology and are vital for cellular processes that involve duplex DNA, namely replication, recombination and transcription [69], [70]. By inhibiting these enzymes, FQs block DNA replication and induce DNA damage, triggering a set of still poorly defined events, which result in eventual cell death. The FQ dependent inhibition of RNA synthesis, and as a consequence protein synthesis, is also thought to contribute to the bactericidal activity of this class of drugs [69], [70]. Unlike most other bacterial species, Mtb lacks genes encoding for topoisomerase IV as revealed by the full genome sequence. Therefore, the main molecular target for FQs in Mtb is the DNA gyrase [71], [72]. Consistently, resistance to FQs in clinical isolates of Mtb occurs primarily due to mutations in the quinolone resistance determining region (QRDR) of the gyrA gene, which encodes for the A subunit of DNA gyrase [73]. Other mechanisms such as mutations in the B subunit of DNA gyrase, decreased cell permeability to the drug, and an active drug efflux pump mechanism could also be involved in triggering resistance. In particular, the expression or overexpression of energy-dependent efflux pumps that can actively remove antibacterial agents from the cell have been shown to play a role in determination of FQ resistance [74-76] TB rather than becoming the workhorse of antimicrobial treatment; however, given the current widespread use of quinolones this might not be realistic. Lately, the interest on FQs as anti-TB agent has focused on the new FQs moxifloxacin and gatifloxacin. Despite a lack of a comprehensive work comparing the activities of old and new classes of FQs in Mtb, what can be inferred from published results is that moxifloxacin and gatifloxacin are characterized by a higher activity against Mtb in vitro when compared to the old FQs ofloxacin and ciprofloxacin [77-80]. These new compounds are currently taken in consideration as anti-TB first-line drugs.

\subsection{Quinolones PD 161148 and CS-940}

The PD 161148 and CS-940 compounds, despite structural similarities [81], both have been selected on the basis of their potent broad-spectrum activity against gram-negative, -positive and anaerobic bacteria, and have been tested against a variety of mycobacteria in comparison to other quinolones. CS-940 was screened against 100 clinical isolates of Mtb and, along with sparfloxacin, was found to be have an average IC50 of $0.25-0.5 \mathrm{mcg} / \mathrm{ml}$ and to be more potent than ofloxacin, ciprofloxacin and balofloxacin (IC50s of 0.5 to $2.0 \mathrm{mcg} / \mathrm{ml}$ ), with norfloxacin (IC50s of 8 to $16 \mathrm{mcg} / \mathrm{ml}$ ) being the least active. PD 161148 was also tested against various clinical isolates of Mtb where it was compared to the desmethoxy analogue and ciprofloxacin and found to be some 3-4-fold more active. Against ciprofloxacin-resistant strains, the presence of the C-8 methoxy group in PD 161148 enhanced lethality. Both PD 161148 and CS-940 are amongst the most active of all third-generation quinolones but unfortunately there are no in-vivo TB data in the public domain which would allow the two compounds to be further separated.

\subsection{Sitafloxacin}

The Daiichi quinolone Sitafloxacin (DU-6859a) has activity against a broad range of bacteria. The mechanistic basis for this potency is believed to reside with sitafloxacin's ability to equally inhibit both DNA gyrase and topoisomerase IV, 
and its IC50s against these enzymes were amongst the lowest of the quinolones [72]. Sitafloxacin was equipotent with gatifloxacin and sparfloxacin, and more active than levofloxacin and ofloxacin, when tested against Mtb -MICs at which $90 \%$ of strains of Mtb inhibited (MIC90s) were $\sim 0.2 \mathrm{mcg} / \mathrm{ml}$. No data appear to have been published for the activity of the compound against $M$. tuberculosis in vivo [82].

\subsection{Gemifloxacin}

Gemifloxacin is another quinolone for the treatment of respiratory infections [83]. The anti-TB potential of gemifloxacin appears to be limited. Gemifloxacin showed a MIC90 value of $8 \mathrm{mcg} / \mathrm{ml}$, compared with $1 \mathrm{mcg} / \mathrm{ml}$ for levofloxacin, trovafloxacin and grepafloxacin [61].

\subsection{Gemifloxacin}

Gatifloxacin has been found to have in vitro and in vivo bactericidal activity against Mtb [77], [78]. Similar results were obtained when gatifloxacin was used in combination with INH or RIF: gatifloxacin was able to slightly increase the bactericidal activity of INH or RIF only during the first 2 days [78]. Thus, available data do not support the hypothesis that introduction of gatifloxacin in first-line regimen will impressively contribute to shorten TB treatment.

\subsection{Moxifloxacin}

Moxifloxacin is the most promising of the new FQs being tested against Mtb. In vitro, moxifloxacin appeared to kill a subpopulation of tubercle bacilli not killed by RIF, while the older FQs ciprofloxacin and ofloxacin did not have any significant bactericidal effect. One possibility is that moxifloxacin interferes with protein synthesis in slowly metabolising bacteria through a mechanism that differs from that used by RIF. In mouse models the activity of moxifloxacin against tubercle bacilli was comparable to that of INH [79]. Moreover, when used in combination with moxifloxacin and PZA, moxifloxacin has been reported to kill the bacilli more effectively than the INH+RIF+PZA combination [85], [87]. In vitro, moxifloxacin inhibitory activity of DNA gyrase is higher than ofloxacin but comparable to ciprofloxacin. In S. pneumoniae, moxifloxacin maintained clinically useful level of activity against bacterial strains that bore mutations in the QRDR region of gyrA genes, suggesting that MXF could target other key domains in the DNA-gyrase enzyme [87] complete culture conversion after 6 months of treatment [88]. Furthermore, no relapse was observed in mice treated for at least 4 months with the combination RIF's moxifloxacin-pyrazinamide, while mice treated with RIF-INH-PZA required 6 months of treatment before no relapse could be detected [89]. The authors explain the better activity of the rifampicin-moxifloxacin-PZA combination over the RIF-INH-PZA combination as the consequence of a possible synergism in the anti-TB activity of the three drugs RIF, moxifloxacin and PZA [90-92].

\section{Mefloquine and analogues}

The antimalarial drug mefloquine (a 4-aminoquinoline methanol), and several analogues, have been reported to have activity against a variety of bacteria including Mycobacterium [93]. From a series of quinolinemethanols obtained from WRAIR, two compounds, WR-3016 and WR-3017, showed potent inhibitory activity in vitro in the M. avium complex1 (MAC) assay with MIC50 values of 1 and $2 \mathrm{mcg} / \mathrm{ml}$ respectively, compared to $16 \mu \mathrm{g} / \mathrm{ml}$ for mefloquine. However, these two compounds were not as active as the parent drug in an in vivo MAC assay. There is also interest in the antiTB properties of the mefloquine analogue desbutylhalofantrine. This compound is in development for its antimalarial properties with the apparent advantage over the parent drug halofantrine of lower cardiotoxicity. In clinical trials, sufficient blood levels were reached to suggest that it would be effective in TB patients.

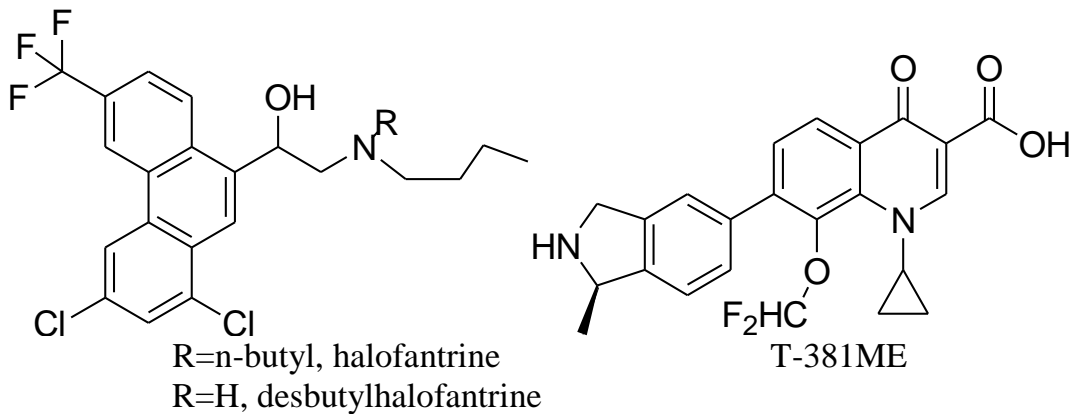


<smiles></smiles>

Levofloxacin<smiles>COc1c(N2C[C@H]3NCCC[C@@H]3C2)c(F)cc2c(=O)c(C(=O)O)cn(C3CC3)c12</smiles>

Trovafloxacin<smiles>CN1CCN(c2cc3c(cc2F)c(=O)c(C(=O)O)cn3C2CC2)CC1</smiles>

Ciprofloxacin moxifloxacin<smiles>COc1c(N2CCNC(C)C2)c(F)cc2c(=O)c(C(=O)O)cn(C3CC3)c12</smiles>

R/S: Gatifloxacin<smiles>C[C@@H]1COc2c(N3CCN(C)CC3)c(F)cc3c(=O)c(C(=O)O)cn1c23</smiles>

R/S: Ofloxacin $\mathrm{S}$ : Levofloxacin<smiles>OC(c1cc(C(F)(F)F)nc2c(C(F)(F)F)cccc12)C1CCCCN1</smiles>

Mefloquine<smiles>C[C@H]1CN(c2c(F)c(N)c3c(=O)c(C(=O)O)cn(C4CC4)c3c2F)C[C@@H](C)N1</smiles>

Sparfloxacin<smiles>CCn1cc(C(=O)O)c(=O)c2cc(F)c(N3C[C@H](C)N[C@H](C)C3)cc21</smiles>

Enofloxacin<smiles>CCC1CN(c2c(F)cc3c(=O)c(C(=O)O)cn(C4CC4)c3c2OC)CCN1</smiles>
PD161148<smiles>OC(C1=CCC=CN1)c1cc(-c2ccc(Cl)cc2)nc2c1ccc1ccccc12</smiles>

WR-3016<smiles>OC(C1=CCC=CN1)c1cc(C2=CC3CCC2CC3)nc2c(Cl)cc(Cl)cc12</smiles>

WR-3017<smiles>CC1CN(c2c(F)cc3c(=O)c(C(=O)O)cn(C4CC4)c3c2OC(F)F)CCN1</smiles>

CS-940<smiles>NC1CN(c2c(F)cc3c(=O)c(C(=O)O)cn(C4CC4F)c3c2Cl)CC12CC2</smiles>

Sitafloxacin<smiles>CON=C1CN(c2c(F)cc3c(=O)c(C(=O)O)cn(C4CC4)c3c2Cl)CC1CN</smiles>

\section{Non-fluorinated quinolones}

A series of 8-methoxy non-fluorinated quinolones (NFQs) have been developed. NFQs lack a 6-fluorine in their quinolone nucleus differentiating them from fluorinated quinolones such as gatifloxacin and moxifloxacin. NFQs target a broad spectrum of bacteria and they seem to act preferentially through inhibition of DNA gyrase [94]. NFQs are currently being tested against Mtb. 


\subsection{T-3811ME}

T-3811ME is unique amongst the other broad-spectrum quinolones featured that it lacks the presence of a fluorine atom at the 6-position of the ring. Since the synthesis of norfloxacin, virtually all of the quinolones of interest have contained this structural feature. However, it shows similar broad spectrum and potent activity against bacteria as the best of the fluoroquinolones. Against ten strains of Mtb, T-3811ME has an MIC90 value of $0.0625 \mathrm{mcg} / \mathrm{ml}$-comparable with ciprofloxacin and levofloxacin, and more active than trovafloxacin.

\subsection{Diarylquinoline TMC207}

Diarylquinoline TMC207 is an extremely promising member of a new class of anti-TB agents. Aproximately 20 molecules of the diarylquinoline series have been shown to have a MIC below $0.5 \mu \mathrm{g} / \mathrm{ml}$ against Mtb H37Rv. The most active compound of the class is TMC207 and its spectrum is unique to mycobacteria. The target and mechanism of action of diarylquinoline TMC207 is different from those of other anti-TB agents implying low probability of crossresistance with existing-TB drugs. The diarylquinoline TMC207 is able to inhibit bacterial growth when tested on MDR-TB isolates. Diarylquinoline TMC207 seems to act by inhibiting the ATP synthase [95], leading to ATP depletion and pH imbalance. Moreover, diarylquinoline TMC207 has potent late bactericidal activity in the established infection in murine TB model. Substitution of RIF, INH or PZA with diarylquinoline TMC207 accelerated activity. In particular, the diarylquinoline- INH- PZA and diarylquinolinerifampicin-PZA combinations cleared the lungs of TB in all the mice after two months. Diarylquinoline TMC207 has been also tested in various combinations with the second line drugs amikacin, PZA, moxifloxacin and ethionamide in mice infected with the drugsusceptible virulent Mtb strain H37Rv. Diarylquinoline containing regimen were more active than the current recommended regimen for MDR-TB amikacin-PZA-moxifloxacinethionamide. A thorough assessment of dyarilquinoline activity against MDR-TB in-vivo would however require testing of animal models infected with MDR bacterial strains.

In this direction, a series of 1-ethyl- and 1-aryl-6-fluoro-1,4-dihydroquinol-4-one derivatives were evaluated for anti-TB and cytotoxic activities. Of these, once derivatives (1) exhibited the preeminent MIC of $1.56 \mu \mathrm{g} / \mathrm{mL}$ against Mtb $\mathrm{H} 37 \mathrm{Rv}$ and also a good selectivity index (SI=>40.06). Further, compound (1) also proved to be a potent anti-TB agent with an EC90 value of $5.75 \mu \mathrm{g} / \mathrm{ml}$. Similarly, a number of fifty-one novel 1-(cyclopropyl/2,4-difluorophenyl/t-butyl)-1,4dihydro-6-fluoro-7-(sub secondary amino)-4-oxoquinoline-3-carboxylic acids and found a potent anti-TB agent (2), which showed MIC of $0.09 \mu \mathrm{M}$ against MTB and MDR-TB respectively. In the in vivo animal model (2) decreased the mycobacterial load in lung and spleen tissues with 2.53 - and $4.88-\log 10$ protections respectively at a dose of $50 \mathrm{mg} / \mathrm{kg}$ body weight [96].

Recently, new quinolone antibacterial agents were observed for their potency against certain types of mycobacterial species in in vitro tests and in experimental animals. With this motivation, a series of pyridobenzoxazine derivatives by replacement of the $\mathrm{N}$-methylpiperazinyl group of Levofloxacin with various basic substituents to investigate the structure-activity relationships between anti-TB activities and basic substituents at the C-10 position. Among the compounds, compound (3), which was a 2,8-diazabicyclo[4.3.0]nonanyl derivative with relatively low lipophilicity, showed the most potent activity against mycobacterial species: the activity was 4- to 32-fold more potent than that of levofloxacin. These results suggested that an increase in the lipophilicity of levofloxacin analogues in part contributed to enhancement of anti-TB activities but that lipophilicity of the compound was not a critical factor affecting the potency [97]. While in the investigation of potency against M. kansasii levofloxacin showed MIC in the range of 0.12$0.25 \mu \mathrm{g} / \mathrm{ml}$ while Moxifloxacin showed the range of $\mathrm{MIC}=\leq 0.06-0.12 \mu \mathrm{g} / \mathrm{mL}$. Inspired with the above activity profile of quinolones, a series of Lamivudine prodrugs bearing FQs (4) were evaluated their efficacy against Mtb H37Rv. All the compounds exhibited an inhibition of $92-100 \%$ at a concentration of $6.25 \mu \mathrm{g} / \mathrm{ml}$. While in ciprofloxacin derivatives, one compound (5) showed in vivo anti-TB activity by reducing the bacterial load in spleen tissue with $0.76-\log 10$ protections and was considered to be moderately active in reducing bacterial count in spleen [98,99]. In continuation, Gatifloxacin derivatives and found a more potent compound (6) in comparison to compound (5). In the in vivo animal model compound (6) decreased the bacterial load in lung and spleen tissues with 3.62- and 3.76-log 10 protections, respectively. With this motivation, he was able to find out a most potent molecule (7) which decreased the bacterial load in lung and spleen tissues with 2.42- and 3.66- $\log 10$ protections, respectively, at $25 \mathrm{mg} / \mathrm{kg}$ body weight [100,101]. Contrarily, 7-[4-(5-amino-1, 3, 4 thiadiazole-2-sulfonyl)]-1-piperazinyl fluoroquinolonic derivatives (8), showed moderate anti-TB activity at MIC of $10 \mu \mathrm{g} / \mathrm{mL}$ compared to INH [102].

In another approach, 3-unsubstituted 4-hydroxyquinolin-2(1H)-one potency against Mtb H37Rv, one compound (9) showed moderate activity of MIC $3.125 \mu \mathrm{g} / \mathrm{mL}$ [103]. Surprisingly, the series of 1-hydroxy-3-oxo-5, 6-dihydro-3Hpyrrolo [3, 2, 1-ij] quinoline-2-carboxylic acid hetarylamides exhibited excellent activity (MIC=0.39-6.25 $\mu \mathrm{g} / \mathrm{mL}) \mathrm{in}$ comparison to (9). The most active compound (10) showed MIC of $0.39 \mu \mathrm{g} / \mathrm{mL}$ against Mtb H37Rv [104]. Whereas, the effect of nitro substitution on quinoline ring, a series of 2-(sub)-3-fluoro/nitro-5,12-dihydro-5-oxobenzothiazolo[3, 2a]quinoline-6-carboxylic acid derivatives were evaluated for in-vitro and in-vivo anti-TB activities against Mtb H37Rv, MDR-TB, and M. smegmatis (MC2), and also tested for the ability to inhibit the supercoiling activity of DNA gyrase from M. smegmatis. Among the thirty-four compounds, 2-(3-(diethylcarbamoyl)piperidin-1-yl)-)-3-fluoro-5,12- 
dihydro-5-oxobenzo thiazolo [3,2-a]quinoline-6-carboxylic acid (11) was found to be the most active compound with MIC of 0.18 and $0.08 \mu \mathrm{M}$ against MTB and MDR-TB, respectively. In the in-vivo animal model (11) decreased the bacterial load in lung and spleen tissues with 2.78 and 3.12- $\log 10$ protections, respectively, at the dose of $50 \mathrm{mg} / \mathrm{kg}$ body weight [105-107]. In another investigation, 6-nitroquinolone (12) was also found to be the most active compound in vitro with MIC of 0.08 and $0.16 \mu \mathrm{M}$ against MTB and MDR-TB, respectively. In the in vivo animal model (12) decreased the bacterial load in lung and spleen tissues with 2.78 and 4.15-log 10 protections, respectively, at the dose of $50 \mathrm{mg} / \mathrm{kg}$ body weight [108]. In an effort to increase the potency of quinolones, a series of [1], [2], [3] Triazolo[4,5h]quinolones were evaluated their anti-TB activity against Mtb H37Rv and further 11 clinically isolated strains of Mtb endowed with different drug resistance. Among all, compound (13) exhibited best activity against all strains with a MIC of $0.5 \mu \mathrm{g} / \mathrm{mL}$ [109]. Whereas in another series of [1,2,3]Triazolo[4,5-h] quinolones, Compounds (14) and (15) exhibited better potency of MIC in the range $0.125-16.0 \mu \mathrm{g} / \mathrm{mL}$ against $\mathrm{H} 37 \mathrm{Rv}$ and 11 clinical isolates of MDR-TB. These results showed that [1], [2], [3]-triazolo[4,5-h] quinolones were endowed with an excellent activity against MDR-TB strains with no cytotoxicity [110].

In the process of investigating novel quinolones as anti-TB agents, many derivatives of quinolones were screened for their in vitro efficacy against MTB and MDR-TB. The most potent (in vitro) compound of the series was screened for in vivo potency too. Compound (16) exhibited MIC99 of $0.19 \mu \mathrm{M}$ and $0.09 \mu \mathrm{M}$ against MTB and MDR-TB, respectively and decreased the bacterial load in lung and spleen tissues with 1.91 and 2.91-log10 protections, respectively, in the in vivo animal model at a dose of $50 \mathrm{mg} / \mathrm{kg}$ body weight [105-107]. Compound (17) decreased the bacterial load in lung and spleen tissues with 2.54 and $2.92-\log 10$ protections [111], while (18) decreased the bacterial load by $30 \%$ and $42 \%$, respectively, at a dose of $50 \mathrm{mg} / \mathrm{kg}$ body weight [105-107]. In an effort to increase the antitubercular potency of quinolones, 1-(cyclopropyl/2,4-difluorophenyl/tert-butyl)-1,4-dihydro-8-methyl-6-nitro-4-oxo-7-(substitutedsecondary-amino)quinoline-3-carboxylic acids. The most active compound (19) of the series showed MIC of $0.42 \mu \mathrm{M}$ and $0.09 \mu \mathrm{M}$ against MTB and MDR-TB respectively [112]. While in an another series, 7-(3-(diethylcarbamoyl) piperidin-1-yl)-1-cyclopropyl-6-fluoro-1, 4-dihydro-4-oxoquinoline-3-carboxylic acid (20) exhibited promising MIC of $0.09 \mu \mathrm{M}$ against MTB and MDR-TB respectively. In the in vivo animal model [20] also decreased the mycobacterial load in lung and spleen tissues with 2.53- and 4.88- $\log 10$ protections respectively at a dose of $50 \mathrm{mg} / \mathrm{kg}$ body weight [108]. With the same motivation, de Moxifloxacin and Gatifloxacin derivatives and evaluated against Mtb H37Rv (MTB). The most active compound (21) exhibited a MIC of $0.31 \mu \mathrm{g} / \mathrm{mL}$ [113]. Thus, developing quinolones as anti-TB agents is a worthy approach.

\section{Quinoline and quinoxaline derivatives}

The start point for the preparation of the quinoline derivatives to be evaluated against TB were quinoline based malaria drugs, such as quinine, chloroquine, mefloquine, primaquine, and amodiaquine which possessed moderate biological activity against TB. In adition, indentification of new promising quinoline based anti-TB agents, 2, 8- dicyclopentyl-4methylquinoline (DCMQ) [114] and Diarylquinoline (TMC207) [115] have definitely initiated the optimization of quinoline for antitubercular drugs. In this concern, 1-(5-isoquinolinesulfonyl)-2-methylpiperazine (22), a protein kinase inhibitor for its anti-TB profile and found to inhibit the growth of two different mycobacterial strains, the slow-growing M. bovis Bacille Calmette Guerin (BCG) and the fast-growing saprophyte M. smegmatis mc2 155, in a dose-dependent manner. While screening for the effect of kinase inhibitors on mycobacterial growth, millimolar concentrations of (22) induced a $40 \%$ decrease in the growth of M. bovis BCG when measured as a function of oxidative phosphorylation. This 1-induced decrease in growth was shown to involve a 2-log fold decrease in the viable counts of M. smegmatis within a $48 \mathrm{~h}$ period and a $50 \%$ reduction in the number of BCG viable counts within a 10-day period. Micromolar concentrations of (22) induced a significant decrease in the activity of the M. tuberculosis protein serine/threonine kinase (PSTK) PknB. The inhibition of mycobacterial growth as well as the inhibition of a representative M. tuberculosis protein serine/threonine kinase PknB suggests that conventional PSTK inhibitors can be used to study the role that the mycobacterial PSTK family plays in controlling bacterial growth [116]. A series of quinolinyl hydrazones and majority of the tested compounds showed an inhibitory activity between 95 and $100 \%$. The most potent compounds of the series $(23 \mathrm{a}-\mathrm{c})$ were having a MIC of $0.78 \mu \mathrm{g} / \mathrm{mL}$. Theese results indicated that the activity was significantly affected by substituents both on the quinoline nucleus and hydrazinoic moiety. On quinoline nucleus the most effective substituents resulted were 6-cyclohexyl, 7-methoxy or ethoxy and 7-chloro groups. Similarly, for the hydrazinoic moiety greater effectiveness resulted for para and ortho-methoxynaphthyl substituents whereas disubstitution with chlorine resulted in inactive compounds [117]. Inspired with the activity profile of DCMQ, four new series of the ringsubstituted quinolinecarbohydrazides, of these 3-quinolinehydrazides and N2-alkyl/N2,N2-dialkyl/N2-aryl-4-(1adamantyl)-2-quinolinecarboxamides showed moderate activity of MIC in the range of $6.25-3.125 \mu \mathrm{g} / \mathrm{mL}$ against $\mathrm{M}$. tuberculosis H37Rv. The most active compounds (24a and 24b) were exhibited MIC value $3.125 \mu \mathrm{g} / \mathrm{mL}$ [118]. Whereas, some quinoline derivatives based on TMC207 and a molecule (25) was active with MIC value $3.12 \mu \mathrm{g} / \mathrm{mL}$ [119]. With the same interest, 3-benzyl-6-bromo-2-methoxy-quinolines and amides of 2-[(6-bromo-2-methoxyquinolin-3-yl)-phenylmethyl]-malonic acid monomethyl ester, four compounds (26a-d) were showed moderate activity of MIC $6.25 \mu \mathrm{g} / \mathrm{mL}$ against M. tuberculosis H37Rv [120]. Most recently, a series of substituted quinolinyl and substituted quinolinyl pyrimidines were evaluated for their in-vitro anti-TB activity against M. tuberculosis H37Rv. 
Among both the series, compounds (27a and 27b) have shown anti-TB activity of MIC $3.12 \mu \mathrm{g} / \mathrm{mL}$ and were nontoxic against VERO, MBMDM cell lines [121]. The anti-TB potential of NAS-91 (28) and has multiple targets, which is particularly desirable for avoiding the emergence of resistant strains of $\mathrm{M}$. tuberculosis. Therefore, NAS-91 represents a potent pharmacophore and appears to be a promising lead compound for future inhibitor development against TB [122]. The quinoline-3-carbohydrazone derivatives were screened for their anti-TB efficacy. Among all, two compounds (29a and 29b) have shown promising activity with a MIC $0.625,2.5$ and $1.25 \mu \mathrm{g} / \mathrm{mL}$ against M. tuberculosis $\mathrm{H} 37 \mathrm{Rv}, \mathrm{M}$. smegmatis and M. fortuitum respectively. These compounds have shown almost equal potency similar to that of standard rifampicin [123]. Whereas in the series of 4-quinolylhydrazones, the most active compound (30) displayed an anti-TB activity of MIC $0.6 \mu \mathrm{M}$ and selectivity index 2.27 [124].

In a similar approach, 7-chloro-4-quinolinylhydrazone derivatives and found three molecules (31a-c) with a moderate antiTB activity with a MIC $2.5 \mu \mathrm{g} / \mathrm{mL}$. These compounds were found to be nontoxic against $\mathrm{J} 774$ cell line up to the concentration $100 \mu \mathrm{g} / \mathrm{ml}$ [125]. In search of novel potent quinoline derivatives, quinoline derivatives consisting of triazolo, ureido and thioureido substituents at C-6 position, of these, ureido derivative (32a) and triazolo derivative (32b) have shown moderate activity of MIC $3.125 \mu \mathrm{g} / \mathrm{mL}$ against $\mathrm{M}$. tuberculosis $\mathrm{H} 37 \mathrm{Rv}$ [126]. With the same motivation, a series of amino acid conjugates of 4-(adamantan-1-yl) group containing quinolines. The most active nontoxic compound (33) of the series exhibited increased potency of $1 \mu \mathrm{g} / \mathrm{mL}$ against $\mathrm{M}$. tuberculosis $\mathrm{H} 37 \mathrm{Rv}$ and 3.125 $\mu \mathrm{g} / \mathrm{mL}$ against drug-resistant strain, in comparison to former molecules (32a and 62b) [127]. In the same direction of approach, quinoline-based derivatives were evaluated for their anti-TB efficiency. Among all, compound (34) has shown remarkable activity of MIC $0.77 \mu \mathrm{M}$ against $\mathrm{M}$. tuberculosis $\mathrm{H} 37 \mathrm{Rv}$ and $0.99-1.55 \mu \mathrm{M}$ against drug-resistant strains [128]. In continuation the same group synthesized isoxazole based quinoline derivatives and found a lead molecule (35), which showed MIC of $0.2 \mu \mathrm{M}$ and 2.6 $\mu \mathrm{M}$ in MABA and LORA assay against M. tuberculosis H37Rv [129]. Thus, optimization of quinolines for the development of anti-TB agents is a fruitful approach. The quinoxaline derivatives show very interesting antimicrobial properties and recently, some researchers have identified the anti-TB activities of various 2- methylquinoxaline 1,4-dioxides, confirming that the presence of a methyl (or halogenomethyl) group at 2(3) position of this ring (36a and 36b) is favourable for antimicrobial activity. In this context as contribution in the development of quinoxaline derivatives, a number of 6(7)-substituted-3-methyl- or 3-halogenomethyl-2phenylthio-phenylsulphonyl-chloro-quinoxaline 1,4-dioxides were screened for their in vitro anti-TB acivity. Among all, two compounds (37a and 37b) exhibited great potency of MIC $0.39 \mu \mathrm{g} / \mathrm{mL}$ against M. tuberculosis, which is comparable to Rifampicin ( $\mathrm{MIC}=0.25 \mu \mathrm{g} / \mathrm{mL}$ ). In another series, four compounds $(38 \mathrm{a}-\mathrm{d})$ have shown moderate activity of MIC $2 \mu \mathrm{g} / \mathrm{mL}$ [130]. In the series of quinoxaline derivatives, lack of 1, 4-dioxide showed reduction in the activity. Most active compound (39) showed MIC of $6.25 \mu \mathrm{g} / \mathrm{mL}$ against MTB H37Rv and $0.5 \mu \mathrm{g} / \mathrm{mL}$ against MTB H37Ra [131]. This prompted to continue the optimization of quinoxaline 1, 4-dioxide. Inspired with the activity profile, a series of quinoxaline-2-carboxamide 1, 4-di-N-oxide derivatives and evaluated for their in vitro anti-TB activity against M. tuberculosis H37Rv [132]. Among all, compound (40a) exhibited best MIC of $0.78 \mu \mathrm{M}$, has a solubility problem, while compound (40b) having MIC of $3.13 \mu \mathrm{M}$ has a best selectivity index ( $\mathrm{SI}=>40.06)$. Same group also synthesized a series of quinoxaline 1,4-di-N-oxide derivatives by varying the 2-position and found that 2 -methylquinoxaline 1,4 -di-Noxides (41a and 41b) were most active of the series with a MIC of $0.39,0.78 \mu \mathrm{M}$ respectively and also have better selectivity index $(8.46,20.43)$ [133]. The compound (41b) is also active against resistant strains of M. tuberculosis [134]. In another series, 2-benzyl-3-(methoxycarbonyl) quinoxaline 1, 4-dioxide (42) has shown best potency above all, with a $\mathrm{MIC}=0.10 \mu \mathrm{g} / \mathrm{mL}$ and selectivity index $\mathrm{SI}=470$ [135]. A new series of 3-phenylquinoxaline 1, 4-di-N-oxide having selectivity against $\mathrm{M}$. tuberculosis have been prepared and evaluated. 34 out of the 70 tested compounds showed an MIC value less than $0.2 \mu \mathrm{g} / \mathrm{mL}$, a value on the order of the MIC of rifampicin. Furthermore, $45 \%$ of the evaluated derivatives showed a good in vitro activity/toxicity ratio. The most active compound was 7-methyl-3-(4'-fluoro) phenylquinoxaline-2-carbonitrile 1, 4-di-N-oxide (43) ( $\mathrm{MIC}<0.2 \mu \mathrm{g} / \mathrm{mL}$ and $\mathrm{SI}>500)$ [136]. In conclusion, the potency, low cytotoxicity and selectivity of these compounds make them valid lead compounds for synthesizing new anti-TB agents. These results prompted for optimization of other quinolone antibacterials to be investigated as anti-TB.<smiles>Nc1ccc(-n2cc(C(=O)O)c(=O)c3cc(F)c(N4CCNCC4)cc32)c(F)c1</smiles>

1<smiles>CCN(CC)C(=O)C1CCCN(c2cc3c(cc2[N+](=O)[O-])c(=O)c(C(=O)O)cn3C2CC2)C1</smiles>

2<smiles>C[C@H]1COc2c(N3C[C@@H]4CCCN[C@@H]4C3)c(F)cc3c(=O)c(C(=O)O)cn1c23</smiles> 


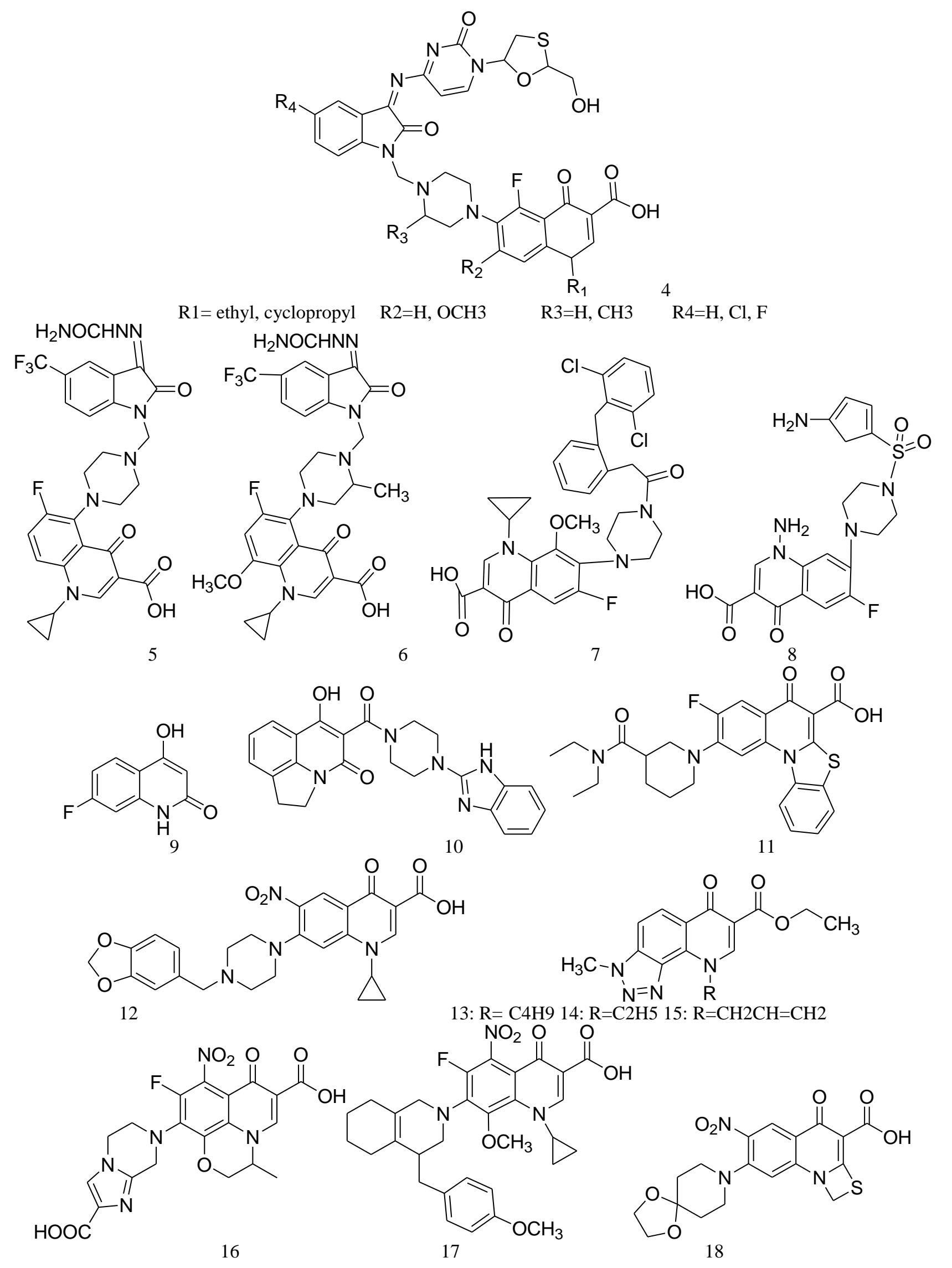


<smiles>Cc1c(N2CCn3cc(C(=O)O)nc3C2)c([N+](=O)[O-])cc2c(=O)c(C(=O)O)cn(C3CC3)c12</smiles>

19<smiles>CCC(CC)C(=O)C1CCCN(c2cc3c(cc2F)c(=O)c(C(=O)O)cn3C2CC2)C1</smiles>

20
21

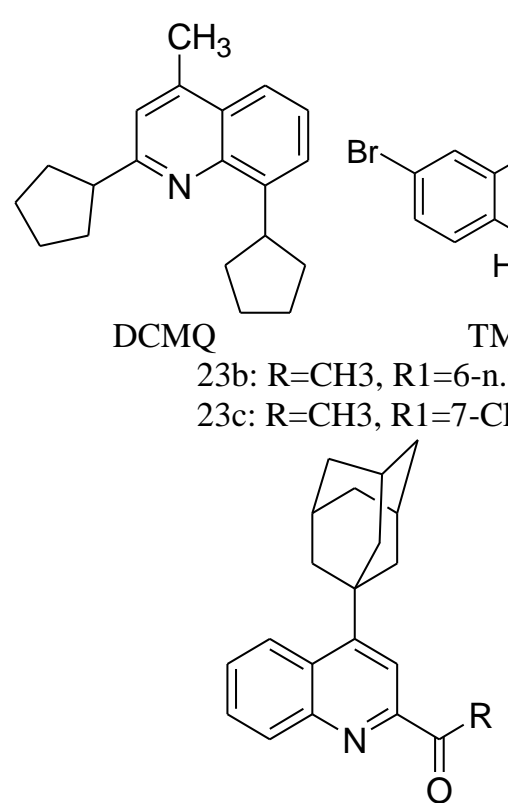

24a: R=anilinyl

24b: $R=$ Phenyl methaminyl

26c: $R=$ Pyrazolyl

26d: $R=6$-Amino-chromen-2-one

$\mathrm{MC} 207$<smiles>NCCCNc1ccnc2cc(Cl)ccc12</smiles>

25<smiles>CC1CNCCN1S(=O)(=O)c1cccc2cnccc12</smiles><smiles>[Z19][R18]1ccc2c(N/N=C/c3ccc(OC)c4ccccc34)cc([R])nc2c1</smiles>
22

23a: R=H, R1=7-OCH3<smiles>[R]C(c1ccccc1)c1cc2cc(Br)ccc2nc1OC</smiles>

26a: R= Imidazolyl

26b: R=C-(Thiophen-2-yl)-methylamine<smiles>[R][R16][Y10]1ccc(Nc2ccc(C(=O)CCc3cccc([R])c3)cc2)c2ccc(Cl)cc12</smiles><smiles>c1ccccc1</smiles><smiles>CSC[C@@H](CC(=O)N(C)C)Nc1c(C(=O)N/N=C/c2cccnc2)cnc2c(C(F)(F)F)cccc12</smiles>

27b: $R=2,5$-dimethoxy 
<smiles>CN(C)C(=O)C[C@@H](CSc1ccccc1)Nc1c(C(=O)N/N=C/c2cccc(OC(F)(F)C(F)F)c2)cnc2c(C(F)(F)F)cc(F)cc12</smiles><smiles>C/C=C\C=C/c1ccc2ccccc2c1/C=N/Nc1ccnc2cc(OC)ccc12</smiles><smiles>[R]c1ccc(/C=N/Nc2ccnc3cc(Cl)ccc23)cc1</smiles><smiles>COc1cccc(NC(=O)Nc2ccc3nc(Oc4ccc(F)cc4C(C)O)c(Cc4ccccc4)cc3c2)c1</smiles><smiles>CC(c1cc(F)ccc1Oc1nc2ccc(-n3nncc3-c3ccccc3)cc2cc1Cc1ccccc1)n1ccnc1</smiles>

$32 \mathrm{a}$<smiles>N=C(N)NCCC[C@H](NC(=O)c1cc(C23CC4CC(CC(C4)C2)C3)c2ccccc2c1)C(N)=O</smiles>

33<smiles>CCOC(=O)c1cc(CCc2cc(C(F)(F)F)nc3cc(C(F)(F)F)cc(C(F)(F)F)c23)on1</smiles>

34<smiles>CCOC(=O)c1cc(/C=C/c2ccnc3ccccc23)on1</smiles>

35<smiles>[R8]C[C@H]1C(Cl)=[N+]([O-])c2cc([R6])c([R2])cc2[NH+]1[O]</smiles>

36a: $\mathrm{R} 1=\mathrm{H}$ 36b: $\mathrm{R} 1=\mathrm{Br}$<smiles>Cc1c(Cl)[n+]([O-])c2cc(F)c(F)cc2[n+]1O</smiles>
$38 \mathrm{~d}$<smiles>[R8]c1cc2c(cc1[R])[n+]([O-])c(Sc1ccccc1)c(C)[n+]2[O-]</smiles>

37a: $\mathrm{R} 1=\mathrm{H}, \mathrm{R} 2=\mathrm{Cl}$ 37b: R1=CF3, R2=H $38 \mathrm{c}: \mathrm{R} 1=\mathrm{R} 2=\mathrm{OCH} 3$<smiles>[R2]c1ccc(Cc2c(C)[n+]([O-])c3cc(F)c(F)cc3[n+]2[O-])cc1[R]</smiles>

38a: $\mathrm{R} 1=\mathrm{H}, \mathrm{R} 2=\mathrm{F}$ 38b: $\mathrm{R} 1=\mathrm{H}, \mathrm{R} 2=\mathrm{OCH} 3$<smiles>[R]c1cc2c(cc1[R])[n+]([O-])c(C(=O)Nc1ccccc1)c(C)[n+]2[O-]</smiles>

40a: $\mathrm{R}=\mathrm{Cl} \quad$ 40b: $\mathrm{R}=\mathrm{H}$ 
<smiles>[R]c1cc2c(cc1Cl)[n+]([O-])c(C)c(C(C)=O)[n+]2[O-]</smiles>

41a: $\mathrm{R}=\mathrm{Cl} \quad 41 \mathrm{~b}: \mathrm{R}=\mathrm{H}$<smiles>COC(=O)c1c(Cc2ccccc2)[n+]([O-])c2ccccc2[n+]1[O-]</smiles>

42<smiles>Cc1ccc2c(c1)[n+]([O-])c(C#N)c(-c1ccc(F)cc1)[n+]2[O-]</smiles>

43

\section{Discussion}

The current molecules in this series will have mainly been selected for further development on the basis of broadspectrum antimicrobial efficacy in short-term treatment regimens. However, for TB chemotherapy it would be beneficial to progress representatives of the series which have a more selective action on mycobacteria at the expense of other microbes. This would help avoid the undesirable effect of severely depleting the beneficial gut fauna. Another approach to identifying a more appropriate anti-TB quinolone would be to select those members of the series concentrating in lung tissues. It would be highly desirable to compare all potential candidates for further progression in a standard series of tests - e.g. efficacy, ADME, toxicity studies in mice, in vitro tests v quinolone-sensitive and resistant strains of M. tuberculosis. The side-effects of the quinolones- particularly the newer fluoroquinolones [137] are phototoxicity, neurotoxicity, and drug-drug interactions (possibly caused by the affinity of these compounds for cytochrome P450). Less frequently observed problems include renal, hepatic and cardiac toxicity. Since the treatment regimens for TB therapy are likely to be longer than for most other bacterial diseases, it is a cause of some concern that these toxicities might occur more frequently and blight a drug marketed for both TB and more commercially attractive diseases [138-142]. Consequently, the selection of a mycobacterial-disease specific drug is attractive despite the additional costs of developing this as a new chemical entity. During quinolone therapy, resistant organisms emerge with a frequency, especially among staphylococci and pseudomonas. Resistance is due to one or more point mutations in the quinolone binding region of the target enzyme or to a change in the permeability of the organism. DNA gyrase is the primary target in E coli, with single-step mutants exhibiting amino acid substitution in the A subunit of gyrase. Topoisomerase IV is a secondary target in E coli that is altered in mutants expressing higher levels of resistance. In staphylococci and streptococci, the situation is reversed: topoisomerase IV is usually the primary target, and gyrase is the secondary target. Resistance to one fluoroquinolone, particularly if of high level, generally confers cross-resistance to all other members of this class. With the increasing use of fluoroquinolones for a variety of infections, including respiratory tract infections, fluoroquinolone resistance has emerged among strains of Streptococcus pneumonia [143$150]$.

\section{Conclusion}

Moreover, the opportunistic TB infection due to AIDs and emergence of drug resistant TB strains has made its chemotherapeutic strategies increasingly ineffective. Traditionally, it has relied heavily on a limited number of drugs such as isoniazid, rifampicin, ethambutal, streptomycin, ethionamide, pyrazinamide, etc. However, many of these drugs have different disadvantages such as prolonged treatment schedules, host toxicity, ineffectiveness against resistant strains etc. This has motivated for the search of new chemical prototypes capable of rapid mycobactericidal action with shortened duration of therapy, reduced toxicity and enhanced activity against drug resistant strains and also against the latent bacteria for its control. Inspite of the availability of various chemotherapeutic agents, TB remains a leading infectious killer worldwide. This is mainly due to the lack of new drugs, particularly for effective treatment against the spread of MDR-TB and XDR-TB strains. Therefore, there is an urgent need for the development of new anti-TB drugs with lesser side-effects, improved pharmacokinetic properties to be effective against both the Gram positive and Gram negative bacteria including the resistant strains. More importantly, the newly developed drugs are required to reduce the overall duration of treatment. It is also important to note that while we pursue the development of new drugs based on inhibition of bacterial targets. In recent years, efforts are being made to develop new molecules based on different scaffolds that act on a number of drug targets. Hence, new molecules that are active against cell wall targets could provide valuable therapeutic options for the therapeutic application including drug resistance. It was also recommended that the family of antibacterial quinolones be further studied in the discovery research phase in an attempt to identify molecules with greater anti-TB potential than current candidates which have been discussed specifically in this report.

\section{References}

[1] Andriole VT. The future of the quinolones. Drugs, 1993, 45(suppl 3), 1-7. http://dx.doi.org/10.2165/00003495-199300453-00003.

[2] Hooper DC. Quinolones. In, Mandell, Douglas, and Bennett's Principles and Practice of Infectious Diseases, 5th ed. (Mandell, G.L, Bennett, J.E, and Dolin, R, Eds.) Churchill Livingstone, New York, 2000, pp. 404-423. 
[3] Sheehan G, Chew NSY. The history of quinolones. In, Fluoroquinolone Antibiotics. (Ronald AR, Low DE, Eds.) Birkhauser, Basel, 2003, 110. http://dx.doi.org/10.1007/978-3-0348-8103-6_1.

[4] Stahlmann R, Lode H. Toxicity of quinolones. Drugs, 1999, 58(Suppl. 2):37-42. http://dx.doi.org/10.2165/00003495-199958002-00007.

[5] Sullivan EA, Kreiswirth BN, Palumbo L, Kapur V, Musser JM, Ebrahimzadeh A, Frieden TR. Emergence of fluoroquinolone-resistant tuberculosis in New York City. Lancet, 1995, 345, 1148-1150. http://dx.doi.org/10.1016/S0140-6736(95)90980-X.

[6] Alangaden GJ, Lerner SA. The clinical use of fluoroquinolones for the treatment of mycobacterial diseases. Clin Infect Dis., 1997, 25, 12131221. http://dx.doi.org/10.1086/516116.

[7] Flamm RK, Vojtko C, Chu DT, Li Q, Beyer J, Hensey D, Ramer N, Clement JJ, Tanaka SK. In vitro evaluation of ABT-719, a novel DNA gyrase inhibitor. Antimicrob Agents Chemother, 1995, 39, 964-970. http://dx.doi.org/10.1128/AAC.39.4.964.

[8] Garay SM. In Tuberculosis, W. N. a. G. Rom, S.M, ed. (Philadelphia: Lippincott Williams \& Wilkins), 2004, 345-394.

[9] Hong Kong Chest Service/British Medica IResearch Council. A controlled study of rifabutin and an uncontrolled study of ofloxacin in the retreatment of patients with pulmonary tuberculosis resistant to isoniazid, streptomycin and rifampicin. . Tuber Lung Dis., 1992, 73 , 59-67. http://dx.doi.org/10.1016/0962-8479(92)90081-T.

[10] Nikonenko BV, Samala R, Einck L, Nacy CA. Rapid, simple in vivo screen for new drugs active against Mycobacterium tuberculosis. Antimicrob Agents Chemother., 2004, 48, 4550-4555. http://dx.doi.org/10.1128/AAC.48.12.4550-4555.2004.

[11] Bagchi MC, Mills D, Basak SC. Quantitative structure-activity relationship (QSAR) studies of quinolone antibacterials against M. fortuitum and M. smegmatis using theoretical molecular descriptors. J. Mol. Model., 2007, 13, 111-120. http://dx.doi.org/10.1007/s00894-006-0133-z.

[12] Daffe M, Brennan PJ, Mcneil M. Predominant structural features of the cell wall arabinogalactan of Mycobacterium tuberculosis as revealed through characterization. J Med Chem., 2007, 50, 2492.

[13] Flynn JL, Chan J. Tuberculosis: latency and reactivation. Infect Immun, 2001, 69, 4195 4201. http://dx.doi.org/10.1128/IAI.69.7.41954201.2001.

[14] Glickman SW, Rasiel EB, Hamilton CD, Kubataev A, Schulman KA. Medicine. A portfolio model of drug development for tuberculosis. Science, 2005, 311, 1246-1247. http://dx.doi.org/10.1126/science.1119299.

[15] Global Alliance for TBdrug development. Tuberculosis. Scientific blue print for tuberculosis drug development. Tuberculosis (Edinb), 2001, 81 Suppl 1, 1-52.

[16] Herbert D, Paramasivan CN, Venkatesan P, Kubendiran G, Prabhakar R, Mitchison DA. Bactericidal action of ofloxacin, sulbactamampicillin, rifampin, and isoniazid on logarithmicand stationary-phase cultures of Mycobacterium tuberculosis. Antimicrob Agents Chemother., 1996, 40, 2296-2299.

[17] Drlica, K, and Zhao, X. DNA gyrase, topoisomerase IV, and the 4-quinolones. Microbiol. Mol. Biol. Rev., 1997, 61:377-392.

[18] Ginsburg AS, Grosset JH, Bishai WR. Fluoroquinolones, tuberculosis, and resistance. Lancet InfectDis, $2003,3,432-442$. http://dx.doi.org/10.1016/S1473-3099(03)00671-6.

[19] Havlir DV, Ellner JJ. Mycobacterium avium complex. In, Mandell, Douglas and Bennett's Principles and Practice of Infectious Diseases, 5th ed. (Mandell, C.L, Dolin, R, and Bennett, J.E, Eds.) Churchill Livingstone, Philadelphia, 2000, pp. 2616-2630.

[20] Hooper DC, Wolfson JS. Fluoroquinolone antimicrobial agents. New Engl. J. Med., 1991, 324:384-394. http://dx.doi.org/10.1056/NEJM199102073240606.

[21] Alovero FL, Pan XS, Morris JE, Manzo RH, Fisher LM. Engineering the specificity of antibacterial fluoroquinolones: benzenesulfonamide modifications at C-7 of ciprofloxacin change its primary target in Streptococcus pneumoniae from topoisomerase IV to gyrase. Antimicrob. Agents Chemother. 2000, 44: 320-325. http://dx.doi.org/10.1128/AAC.44.2.320-325.2000.

[22] Mitscher LA, Ma Z. Structure-activity relationships of quinolones. In, Fluoroquinolone Antibiotics. (Ronald, A.R, and Low, D.E, eds.) Birkhauser, Basel, 2003, pp. 11-48. http://dx.doi.org/10.1007/978-3-0348-8103-6_2.

[23] Eliopoulos GM, Eliopoulos CT. Activity in vitro of the quinolones. In, Quinolone Antimicrobial Agents, 2d ed. (Hooper DC, Wolfson JS, Eds.) American Society for Microbiology, Washington, 1993, 161-193.

[24] Leysen DC, Haemers A, Pattyn SR. Mycobacteria and the new quinolones. Antimicrob. Agents Chemother, 1989, 33:1-5. http://dx.doi.org/10.1128/AAC.33.1.1.

[25] Medical Letter. Gatifloxacin and moxifloxacin: Two new fluoroquinolones. Med. Lett. Drugs Ther, 2000, 42:15-17.

[26] Gold HS, Moellering RC Jr. Antimicrobial-drug resistance. New Engl. J. Med, 1996, 335, 1445-1453. http://dx.doi.org/10.1056/NEJM199611073351907.

[27] Oethinger M, Kern WV, Jellen-Ritter AS, McMurry LM, Levy SB. Ineffectiveness of topoisomerase mutations in mediating clinically significant fluoroquinolone resistance in Escherichia coli in the absence of the AcrAB efflux pump. Antimicrob. Agents Chemother, 2000, 44:10-13. http://dx.doi.org/10.1128/AAC.44.1.10-13.2000.

[28] Pegues DA, Colby C, Hibberd PL, et al., The epidemiology of resistance to ofloxacin and oxacillin among clinical coagulase-negative staphylococcal isolates: Analysis of risk factors and strain types. Clin. Infect. Dis., 1998, 26:72-79. http://dx.doi.org/10.1086/516270.

[29] Peterson LR, Lissack LM, Canter K, et al., Therapy of lower extremity infections with ciprofloxacin in patients with diabetes mellitus, peripheral vascular disease, or both. Am. J. Med, 1989, 86, 801-808. http://dx.doi.org/10.1016/0002-9343(89)90476-2.

[30] Smith KE, Besser JM, Hedberg CW, et al., Quinolone-resistant Campylobacter jejuni infections in Minnesota, 1992-1998. Investigation team. New Engl. J. Med., 1999, 340: 1525-1532. http://dx.doi.org/10.1056/NEJM199905203402001.

[31] Thornsberry C, Ogilvie P, Kahn J, Mauriz Y. Surveillance of antimicrobial resistance in Streptococcus pneumoniae, Haemophilus influenzae, and Moraxella catarrhalis in the United States in 1996-1997 respiratory season. Diagn. Microbiol. Infect. Dis., 1997, 29, $249-257$. http://dx.doi.org/10.1016/S0732-8893(97)00195-8.

[32] Centers for Disease Control and Prevention. Decreased susceptibility of Neisseria gonorrhoeae to fluoroquinolones $3 / 4$ Ohio and Hawaii, $1992-$ 1994. M.M.W.R, 1994, 43, 325-327.

[33] Molbak K, Baggesen D.L, Aarestrup FM, et al., (1999). An outbreak of multidrug-resistant, quinolone-resistant Salmonella enterica serotype typhimurium DT104. New Engl. J. Med., 1999, 341, 1420-1425. http://dx.doi.org/10.1056/NEJM199911043411902.

[34] Warren JW, Abruytyn E, Hebel JR, et al., Guidelines for antimicrobial treatment of uncomplicated acute bacterial cystitis and acute pyelonephritis in women. Clin. Infect. Dis., 1999, 29:745-758. http://dx.doi.org/10.1086/520427.

[35] Newman LM, Wang SA, Ohye RG, et al., The epidemiology of fluoroquinolone-resistant Neisseria gonorrhoeae in Hawaii, 2001. Clin. Infect. Dis., 2004, 38:649-654. http://dx.doi.org/10.1086/381546.

[36] Centers for Disease Control and Prevention. Guidelines for treatment of sexually transmitted diseases. M.M.W.R, 1998, 47, 1-111.

[37] DuPont HL, Ericsson CD. Prevention and treatment of traveler's diarrhea. New Engl. J. Med., 1993, 328, $1821-1827$. http://dx.doi.org/10.1056/NEJM199306243282507.

[38] Bennish ML, Salam MA, Khan WA, Khan AM. Treatment of shigellosis: III. Comparison of one- or two-dose ciprofloxacin with standard 5day therapy. A randomized, blinded trial. Ann. Intern. Med., 1992, 117:727-734. http://dx.doi.org/10.7326/0003-4819-117-9-727.

[39] Bhattacharya SK, Bhattacharya MK, Dutta P, et al., Double-blind, randomized, controlled clinical trial of norfloxacin for cholera. Antimicrob. Agents Chemother., 1990, 34, 939-940. http://dx.doi.org/10.1128/AAC.34.5.939.

[40] Khan WA, Seas C, Dhar U, Salam MA, Bennish ML. Treatment of shigellosis: V. Comparison of azithromycin and ciprofloxacin. A doubleblind, randomized, controlled trial. Ann. Intern. Med., 1997, 126, 697-703. http://dx.doi.org/10.7326/0003-4819-126-9-199705010-00004. 
[41] Miedouge M, Hacini J, Grimont F, Watine J. Shiga toxin-producing Escherichia coli urinary tract infection associated with hemolytic-uremic syndrome in an adult and possible adverse effect of ofloxacin therapy. Clin. Infect. Dis., 2000, 30, 395-396. http://dx.doi.org/10.1086/313668.

[42] Aubier M, Verster R, Reganney C, Geslin P, Vercken JB. Once-daily sparfloxacin versus high-dosage amoxicillin in the treatment of community-acquired suspected pneumococcal pneumonia in adults. Sparfloxacin European Study Group. Clin. Infect. Dis., 1998, 26, 13121320. http://dx.doi.org/10.1086/516366.

[43] File TM Jr, Segreti J, Dunbar L, et al., A multicenter, randomized study comparing the efficacy and safety of intravenous and/or oral levofloxacin versus ceftriaxone and/or cefuroxime axetil in treatment of adults with community-acquired pneumonia. Antimicrob. Agents Chemother, 1997, 41, 1965-1972.

[44] Yu VL. Legionella pneumophila (Legionnaires' disease). In, Mandell, Douglas, and Bennett's Principles and Practice of Infectious Diseases, 5th ed. (Mandell GL, Bennett JE, Dolin R, Eds.) Churchill Livingstone, New York, 2000, 2424-2435.

[45] Chen DK, McGeer A, de Azavedo JC, Low DE. Decreased susceptibility of Streptococcus pneumoniae to fluoroquinolones in Canada. Canadian Bacterial Surveillance Network. New Engl. J. Med., 1999, 341, 233-239. http://dx.doi.org/10.1056/NEJM199907223410403.

[46] Wortmann GW, Bennett SP. Fatal meningitis due to levofloxacin-resistant Streptococcus pneumoniae. Clin. Infect. Dis., 1999, 29:1599-1600. http://dx.doi.org/10.1086/313557.

[47] Gentry LO, Rodriguez-Gomez G. Ofloxacin versus parenteral therapy for chronic osteomyelitis. Antimicrob. Agents Chemother, 1991, 35, 538-541. http://dx.doi.org/10.1128/AAC.35.3.538.

[48] Chocarro A, Gonzalez A, Garcia I. Treatment of tularemia with ciprofloxacin. Clin. Infect. Dis., 2000, 31, 623. http://dx.doi.org/10.1086/313946.

[49] Swartz MN. Recognition and management of anthrax: An update. New Engl. J. Med., 2001, 345, 1621-1626. http://dx.doi.org/10.1056/NEJMra012892.

[50] Mandell LA. Improved safety profile of newer fluoroquinolone. In, Fluoroquinolone Antibiotics. (Ronald, A.R, and Low, D.E, Eds.) Birkhauser, Basel, 2003, pp. 73-86. http://dx.doi.org/10.1007/978-3-0348-8103-6_4

[51] Schwartz J, Jauregui L, Lettieri J, Bachmann K. Impact of ciprofloxacin on theophylline clearance and steady-state concentrations in serum. Antimicrob. Agents Chemother, 1998, 32, 75-77. http://dx.doi.org/10.1128/AAC.32.1.75.

[52] Halliwell RF, Davey PG, Lambert JJ. Antagonism of GABA receptors by 4-quinolones. J. Antimicrob. Chemother. $1993,31,457-462$. http://dx.doi.org/10.1093/jac/31.4.457.

[53] Burkhardt JE, Walterspeil JN, Schaad UB. Quinolone arthropathy in animals versus children. Clin. Infect. Dis., 1997, 25, 1196-1204. http://dx.doi.org/10.1086/516119.

[54] Kamal A, Azeeza S, Malik MS, Shaik AA, Rao MV. Efforts towards the development of new antitubercular agents: potential for thiolactomycin based compounds. J Pharm Pharmaceut Sci, 2008, 11 (2): 56s-80s.

[55] Center for Disease Control. Emergence of Mycobacterium tuberculosis with extensive resistance to second-line drugs--worldwide, $2000-2004$. MMWR Morb Mortal Wkly Rep, 2006, 55, 301-305.

[56] Gray MA. Tuberculosis Drugs. Orthopaedic Nursing, 1997, 16(4), 64-69. http://dx.doi.org/10.1097/00006416-199707000-00014.

[57] Gupta UD, Katoch VM. Animal models of tuberculosis. Tuberculosis (Edinb,) 2005, 85, 277-293. http://dx.doi.org/10.1016/j.tube.2005.08.008

[58] Janin YL. Antituberculosis drugs: Ten years of research. Bioorg. Med. Chem., 2007, 15, 2479-2513. http://dx.doi.org/10.1016/j.bmc.2007.01.030.

[59] O'Brien RJ, Nunn PP. The need for new drugs against tuberculosis. Obstacles, opportunities, and next steps. Is J Respir Crit Care Med., 2001, 163, 1055-1058? http://dx.doi.org/10.1164/ajrccm.163.5.2007122.

[60] WHO report: The Stop TB Strategy, case reports, treatment outcomes and estimates of TB burden, 2008. http://www.who.int/tb/publications/global_report/2008/annex_3/en/index.html.

[61] Ruiz-Serrano MJ, Alcala L, Martinez L, Diaz M, Marin M, Gonzalez-Abad MJ, Bouza E. In vitro activities of six fluoroquinolones against 250 clinical isolates of Mycobacterium tuberculosis susceptible or resistant to first-line antituberculosis drugs. Antimicrob Agents Chemother, 2000, 44, 2567-2568. http://dx.doi.org/10.1128/AAC.44.9.2567-2568.2000.

[62] Smith CV, Sharma V, Sacchettini JC. TB drug discovery: Addressing issues of persistence and resistance. Tuberculosis, $2004,84,45-55$. http://dx.doi.org/10.1016/j.tube.2003.08.019.

[63] Russell DG. Mycobacterium tuberculosis: here today, and here tomorrow. Nat Rev Mol Cell Biol., 2001,2 , 569-577. http://dx.doi.org/10.1038/35085034.

[64] Sunduru N, Sharma M, Chauhan PMS. Recent advances in the design and synthesis of Heterocycles as anti-tubercular agents. Future Med Chem., 2010, 2(9), 1469-1500. http://dx.doi.org/10.4155/fmc.10.227.

[65] Grosset JH. Treatment of tuberculosis in HIV infection. Tuber Lung Dis., 1992, 73, 378-383. http://dx.doi.org/10.1016/0962-8479(92)90044$\underline{\text { K. }}$.

[66] Alangaden GJ, Manavathu EK, Vakulenko SB, Zvonok NM, Lerner SA. Characterization of fluoroquinolone-resistant mutant strains of Mycobacterium tuberculosis selected in the laboratory and isolated from patients. Antimicrob Agents Chemother, 1995, 39, $1700-1703$. http://dx.doi.org/10.1128/AAC.39.8.1700.

[67] Ginsburg AS, Hooper N, Parrish N, Dooley KE, Dorman SE, Booth J, Diener-West M, Merz WG, Bishai WR, Sterling TR. Fluoroquinolone resistance in patients with newly diagnosed tuberculosis. Clin Infect Dis, 2003, 37, 1448-1452. http://dx.doi.org/10.1086/379328.

[68] Bozeman L, Burman W, Metchock B, Welch L, Weiner M. Fluoroquinolone Susceptibility among Mycobacterium tuberculosis Isolates from the United States and Canada. Clin Infect Dis., 2005, 40, 386-391. http://dx.doi.org/10.1086/427292.

[69] Lewin CS, Howard BM, Smith JT. 4-Quinolone interactions with gyrase subunit B inhibitors. J Med Microbiol, 1991, 35, 358-362. http://dx.doi.org/10.1099/00222615-35-6-358.

[70] Willmott CJ, Critchlow SE, Eperon IC, Maxwell A. The complex of DNA gyrase and quinolone drugs with DNA forms a barrier to transcription by RNA polymerase. J MolBiol, 1994, 242, 351-363. http://dx.doi.org/10.1006/jmbi.1994.1586.

[71] Aubry A, Pan XS, Fisher LM, Jarlier V, Cambau E. Mycobacterium tuberculosis DNA gyrase: interaction with quinolones and correlation with antimycobacterial drug activity. Antimicrob Agents Chemother., 2004, 48, 1281-1288. http://dx.doi.org/10.1128/AAC.48.4.12811288.2004.

[72] Onodera Y, Tanaka M, Sato K. Inhibitory activity of quinolones against DNA gyrase of Mycobacterium tuberculosis. JAntimicrobChemother., 2001, 47, 447-450. http://dx.doi.org/10.1093/jac/47.4.447.

[73] Kocagoz T, Hackbarth CJ, Unsal I, Rosenberg EY, Nikaido H, Chambers HF. Gyrase mutations in laboratory-selected, fluoroquinolone resistant mutants of Mycobacterium tuberculosis H37Ra. Antimicrob Agents Chemother, 1996, 40, 1768-1774.

[74] Li XZ, Zhang L, Nikaido H. Efflux pump-mediated intrinsic drug resistance in Mycobacterium smegmatis. Antimicrob Agents Chemother. 2004, 48, 2415-2423. http://dx.doi.org/10.1128/AAC.48.7.2415-2423.2004.

[75] Zhanel GG, Hoban DJ, Schurek K, Karlowsky JA. Role of efflux mechanisms on fluoroquinolone resistance in Streptococcus pneumoniae and Pseudomonas aeruginosa. Int J Antimicrob Agents., 2004, 24, 529-535. http://dx.doi.org/10.1016/j.ijantimicag.2004.08.003.

[76] Brenwald NP, Gill MJ, Wise R. Prevalence of a putative efflux mechanism among fluoroquinolone-resistant clinical isolates of Streptococcus pneumoniae. Antimicrob Agents Chemother., 1998, 42, 2032-2035. 
[77] Hu Y, Coates AR, Mitchison DA. Sterilizing activities of fluoroquinolones against rifampin-tolerant populations of Mycobacterium tuberculosis. AntimicrobAgents Chemother., 2003, 47, 653-657. http://dx.doi.org/10.1128/AAC.47.2.653-657.2003.

[78] Paramasivan CN, Sulochana S, Kubendiran G, Venkatesan P, Mitchison DA. Bactericidal action of gatifloxacin, rifampin, and isoniazid on logarithmic- and stationary-phase cultures of Mycobacterium tuberculosis. Antimicrob Agents Chemother, 2005 , 49, 627-631. http://dx.doi.org/10.1128/AAC.49.2.627-631.2005.

[79] Rodriguez JC, Ruiz M, Climent A, Royo G. In vitro activity of four fluoroquinolones against Mycobacterium tuberculosis. Int J Antimicrob Agents, 2001, 17, 229-231. http://dx.doi.org/10.1016/S0924-8579(00)00337-X.

[80] Sulochana S, Rahman F, Paramasivan CN. In vitro activity of fluoroquinolones against Mycobacterium tuberculosis. JChemother., 2005, 17, 169-173. http://dx.doi.org/10.1179/joc.2005.17.2.169.

[81] Biedenbach DJ, Sutton LD, Jones RN. Antimicrobial activity of CS-940, a new trifluorinated quinolone. Antimicrobial Agents and Chemother, 1995, 39(10): 2325-2330. http://dx.doi.org/10.1128/AAC.39.10.2325.

[82] Houston AK, Jones RN. Postantibiotic effect of DU-6859a and levofloxacin as compared with ofloxacin. Diagnostic Microbiol \& Infec Dis, 1994, 18(1), 57-59. http://dx.doi.org/10.1016/0732-8893(94)90134-1.

[83] Moxifloxacin: A new antimicrobial agent. Presented at the 40th CAAC Meeting, Toronto, and September 17-20, 2000. Reported by Pireh D. ID Weekly Highlights, 2000, October, 32-33.

[84] Miyazaki E, Miyazaki M, Chen, JM, Chaisson RE, Bishai WR. Moxifloxacin (BAY12-8039), a new 8-methoxyquinolone, is active in a mouse model of tuberculosis. AntimicrobAgents Chemother., 1999, 43, 85-89.

[85] Daporta MT, Munoz Bellido JL, Guirao GY, Hernandez MS,Garcia-Rodriguez JA. In vitro activity of older and newer fluoroquinolones against efflux-mediated high level ciprofloxacinresistant Streptococcus pneumoniae. Int J Antimicrob Agents., $2004,24,185-187$. http://dx.doi.org/10.1016/j.ijantimicag.2004.01.012.

[86] Coyle EA, Kaatz GW, Rybak MJ. Activities of newer fluoroquinolones against ciprofloxacin-resistant Streptococcus pneumoniae. Antimicrob Agents Chemother, 2001, 45, 1654-1659. http://dx.doi.org/10.1128/AAC.45.6.1654-1659.2001.

[87] Pestova E, Millichap JJ, Noskin GA, Peterson LR. Intracellular targets of moxifloxacin: a comparison with other fluoroquinolones. JAntimicrobChemother, 2000, 45, 583-590. http://dx.doi.org/10.1093/jac/45.5.583.

[88] Nuermberger EL, Yoshimatsu T, Tyagi S, O'Brien RJ, Vernon AN, Chaisson RE, Bishai WR, Grosset JH. Moxifloxacin-containing regimen greatly reduces time to culture conversion in murine tuberculosis. AmJRespirCrit Care Med., 2004, 169, 421-426. http://dx.doi.org/10.1164/rccm.200310-1380OC.

[89] Nuermberger EL, Yoshimatsu T, Tyagi S, Williams K, Rosenthal I, O'Brien RJ, Vernon AA, Chaisson RE, Bishai WR, Grosset JH. Moxifloxacin-containing regimens of reduced duration produce a stable cure in murine tuberculosis. AmJRespirCrit Care Med., 2004, 170, 1131-1134. http://dx.doi.org/10.1164/rccm.200407-8850C.

[90] Grosset J, Truffot-Pernot C, Lacroix C, Ji B. Antagonism between isoniazid and the combination pyrazinamide-rifampin against tuberculosis infection in mice. Antimicrob Agents Chemother, 1992, 36, 548-551. http://dx.doi.org/10.1128/AAC.36.3.548.

[91] Ginsburg AS, Sun R, Calamita H, Scott CP, Bishai WR, Grosset JH. Emergence of fluoroquinolone resistance in Mycobacterium tuberculosis during continuously dosed moxifloxacin monotherapy in a mouse model. AntimicrobAgents Chemother., 2005, 49, 3977-3979. http://dx.doi.org/10.1128/AAC.49.9.3977-3979.2005.

[92] Burman WJ, Goldberg S, Johnson JL, Muzanye G, Engle M, Mosher AW, Choudhri S, Daley CL, Munsiff SS, Zhao Z, et al., Moxifloxacin versus ethambutol in the first 2 months of treatment for pulmonary tuberculosis. Is J Respir Crit Care Med., 2006, 174, 331-338? http://dx.doi.org/10.1164/rccm.200603-3600C.

[93] Kunin CM, Ellis WY. Antimicrobial activities of mefloquine and a series of related compounds. Antimicrobial Agents \& Chemother, 2000, 44(4):848-852. http://dx.doi.org/10.1128/AAC.44.4.848-852.2000.

[94] Jones, P. B, Parrish, N. M, Houston, T. A, Stapon, a, Bansal, N. P, Dick, J. D, and Townsend, C. A. A new class of antituberculosis agents. J Med Chem, 2000, 43, 3304-3314. http://dx.doi.org/10.1021/jm0001491.

[95] Petrella S, Cambau E, Chauffour A, Andries K, Jarlier V, Sougakoff W. Genetic basis for natural and acquired resistance to the diarylquinoline R207910 in mycobacteria. Antimicrob Agents Chemother, 2006, 50, 2853-2856. http://dx.doi.org/10.1128/AAC.00244-06.

[96] Senthilkumar P, Dinakaran M, Yogeeswari P, China A, Nagaraja V, Sriram D. Antimycobacterial activities of novel fluoroquinolones. Biomedicine Pharmacother., 2009, 63(1), 27-35. http://dx.doi.org/10.1016/j.biopha.2007.10.004.

[97] Kawakami K, Namba K, Tanaka M, Matsuhashi N, Sato K, Takemura M. Antimycobacterial Activities of Novel Levofloxacin Analogues. Antimicrob. Agents Chemother, 2000, 44(8), 2126-2129. http://dx.doi.org/10.1128/AAC.44.8.2126-2129.2000.

[98] Sriram D, Yogeeswari P, Basha JS, Radha DR, Nagaraja V. Synthesis and antimycobacterial evaluation of various 7-substituted ciprofloxacin derivatives. Bioorg. Med. Chem., 2005, 13(20), 5774-5778. http://dx.doi.org/10.1016/j.bmc.2005.05.063.

[99] Sriram D, Yogeeswari P, Madhu K. Synthesis and in vitro and in vivo antimycobacterial activity of isonicotinoyl hydrazones. Bioorg. Med. Chem. Lett., 2005, 15(20), 4502-4505. http://dx.doi.org/10.1016/j.bmcl.2005.07.011.

[100] Sriram D, Aubry A, Yogeeswari P, Fisher LM. Gatifloxacin derivatives: Synthesis, antimycobacterial activities, and inhibition of Mycobacterium tuberculosis DNA gyrase. Bioorg. Med. Chem. Lett., 2006, 16(11), 2982-2985. http://dx.doi.org/10.1016/j.bmcl.2006.02.065.

[101] Sriram D, Yogeeswari P, Thirumurugan R, Pavana RK. Discovery of New Antitubercular Oxazolyl Thiosemicarbazones. J. Med. Chem., 2006, 49(12), 3448-3450. http://dx.doi.org/10.1021/jm060339h.

[102] Talatha S, Gadad AK. Synthesis, antibacterial and antitubercular activities of some 7-[4-(5-amino-[1, 3, 4] thiadiazole-2-sulfonyl)-piperazin-1yl] fluoroquinolonic derivatives. Eur. J. Med. Chem., 2006, 41(8), 918-924. http://dx.doi.org/10.1016/j.ejmech.2006.03.027.

[103] Arya K, Agarwal M. Microwave prompted multigram synthesis, structural determination, and photo-antiproliferative activity of fluorinated 4hydroxyquinolinones. Bioorg. Med. Chem. Lett., 2007, 17(1), 86-93. http://dx.doi.org/10.1016/j.bmcl.2006.09.082.

[104] Ukrainets IV, Mospanova EV, Sidorenko LV. 4-hydroxy-2-quinolones. 1- hydroxy-3-oxo-5, 6-dihydro-3h-pyrrolo [3, 2, 1-ij]-Quinoline-2carboxylic acid hetarylamides as potential antitubercular agents. Chem. Heterocycl. Comp., 2007, 43(7), 863-870. http://dx.doi.org/10.1007/s10593-007-0137-3.

[105] Dinakaran M, Senthilkumar P, Yogeeswari P, China A, Nagaraja V, Sriram D. Antimycobacterial and phototoxic evaluation of novel 6fluoro/nitro-4-oxo-7-(sub)-4H-[1, 3] thiazeto [3, 2-a] quinoline-3-carboxylic acid. Int. J. Antimicrob. Agents. 2008, 31(4), 337-344. http://dx.doi.org/10.1016/j.ijantimicag.2007.12.007.

[106] Dinakaran M, Senthilkumar P, Yogeeswari P, China A, Nagaraja V, Sriram D. Antimycobacterial activities of novel 2-(sub)-3-fluoro/nitro-5, 12-dihydro-5- oxobenzothiazolo[3,2-a]quinoline-6-carboxylic acid. Bioorg. Med. Chem., 2008, 16(6), 3408-3418. http://dx.doi.org/10.1016/j.bmc.2007.11.016.

[107] Dinakaran M, Senthilkumar P, Yogeeswari P, and China a, Nagaraja V, Sriram D. Novel ofloxacin derivatives: Synthesis, antimycobacterial and toxicological evaluation. Bioorg. Med. Chem. Lett., 2008, 18(3), 1229-1236. http://dx.doi.org/10.1016/j.bmcl.2007.11.110.

[108] Senthilkumar P, Dinakaran M, Yogeeswari P, Sriram D, China A, Nagaraja V. Synthesis and antimycobacterial activities of novel 6nitroquinolone-3-carboxylic acids. Eur. J. Med. Chem., 2009, 44(1), 345-358. http://dx.doi.org/10.1016/j.ejmech.2008.02.031.

[109] Carta A, Palomba M, Paglietti G, Molicotti P, Paglietti B, Cannas S, Zanetti S. [1, 2, 3] Triazolo [4, 5-h] quinolones. A new class of potent antitubercular agents against multidrug resistant Mycobacterium tuberculosis strains. Bioorg. Med. Chem. Lett., 2007, 17(17), 4791-4794. http://dx.doi.org/10.1016/j.bmcl.2007.06.064. 
[110] Carta A, Piras S, Palomba M, Jabes D, Molicotti P, Zanetti S. Anti- Mycobacterial Activity of Quinolones. Triazoloquinolones a New Class of Potent Anti-Mycobacterial Agents. Anti-Infective Agents in Med. Chem., 2008, 7(2), 134-147.

[111] Senthilkumar P, Dinakaran M, Banerjee D, Devakaram RV, Yogeeswari P, China A, Nagaraja V, Sriram D. Synthesis and antimycobacterial evaluation of newer 1-cyclopropyl-1,4-dihydro-6-fluoro-7-(substituted secondary amino)-8-methoxy-5-(sub)-4-oxoquinoline-3-carboxylic acids. Bioorg. Med. Chem., 2008, 16(5), 2558-2569. http://dx.doi.org/10.1016/j.bmc.2007.11.050.

[112] Senthilkumar P, Dinakaran M, Chandraseakaran Y, Yogeeswari P, Sriram D. Synthesis and in-vitro Antimycobacterial Evaluation of 1(Cyclopropyl/2,4-difluorophenyl/tert-butyl)-1,4-dihydro-8-methyl-6-nitro-4-oxo-7-(substituted secondary amino)quinoline-3-carboxylic acids. Arch. Pharm. Chem. Life Sci., 2008, 342(2), 100-112. http://dx.doi.org/10.1002/ardp.200800015.

[113] de Almeida MV, Saraiva MF, de Souza MVN, da Costa CF, Vicente FRC, Lourenco MCS. Synthesis and antitubercular activity of lipophilic moxifloxacin and gatifloxacin derivatives. Bioorg. Med. Chem. Lett., 2007, 17 (20), 5661-5664. http://dx.doi.org/10.1016/j.bmcl.2007.07.073.

[114] Jain R, Vaitilingam B, Nayyar A, Palde PB. Substituted 4-Methylquinolines as a New Class of Anti-Tuberculosis Agents. Bioorg. Med. Chem. Lett., 2003, 13(6), 1051- 1054. http://dx.doi.org/10.1016/S0960-894X(03)00074-X.

[115] Gaurrand S, Desjardins S, Meyer C et al., Conformational Analysis of R207910, a New Drug Candidate for the Treatment of Tuberculosis, by a Combined NMR and Molecular Modeling Approach. Chem. Biol. Drug Des., 2006, 68(2), 77-84. http://dx.doi.org/10.1111/j.17470285.2006.00410.x.

[116] Drews SJ, Hung F, Av-Gay Y. A protein kinase inhibitor as an antimycobacterial agent. FEMS Microbiol. Lett., $2001,205(2)$, $369-374$. http://dx.doi.org/10.1111/j.1574-6968.2001.tb10974.x.

[117] Savini L, Chiasserini L, Gaeta A, Pellerano C. Synthesis and Anti-tubercular Evaluation of 4-Quinolylhydrazones. Bioorg. Med. Chem., 2002, 10(7), 2193-2198. http://dx.doi.org/10.1016/S0968-0896(02)00071-8.

[118] Monga V, Nayyar A, Vaitilingam B, et al., Ring-substituted quinolines. Part 2: Synthesis and antimycobacterial activities of ring-substituted quinolinecarbohydrazide and ring-substituted quinolinecarboxamide analogues. Bioorg. Med. Chem., 2004, 12(24), 6465-6472. http://dx.doi.org/10.1016/j.bmc.2004.09.017.

[119] de Souza MVN, Pais KC, Kaiser CR, Peralta MA, Ferreira ML, Lourenço MCS. Synthesis and in vitro antitubercular activity of a series of quinoline derivatives. Bioorg. Med. Chem., 2009, 17(4), 1474-1480. http://dx.doi.org/10.1016/j.bmc.2009.01.013.

[120] Upadhayaya RS, Kulkarni GM, Vasireddy NR et al., Design, synthesis and biological evaluation of novel triazole, urea and thiourea derivatives of quinoline against Mycobacterium tuberculosis. Bioorg. Med. Chem., 2009, 17(13), 4681-4692. http://dx.doi.org/10.1016/j.bmc.2009.04.069.

[121] Sharma M, Chaturvedi V, Manju YK et al., Substituted quinolinyl chalcones and quinolinyl pyrimidines as a new class of anti-infective agents. Eur. J. Med. Chem., 2009, 44(5), 2081-2091. http://dx.doi.org/10.1016/j.ejmech.2008.10.011.

[122] Gratraud P, Surolia N, Besra GS, Surolia A, Kremer L. Antimycobacterial Activity and Mechanism of Action of NAS-91. Antimicrob. Agents Chemother., 2008, 52(3), 1162-1166. http://dx.doi.org/10.1128/AAC.00968-07.

[123] Eswaran S, Adhikari AV, Pal NK, Chowdhury IH. Design and synthesis of some new quinoline-3-carbohydrazone derivatives as potential antimycobacterial agents. Bioorg. Med. Chem. Lett., 2010, 20(3), 1040-1044. http://dx.doi.org/10.1016/j.bmcl.2009.12.045.

[124] Gemma S, Savini L, Altarelli M et al., Development of antitubercular compounds based on a 4-quinolylhydrazone scaffold. Further structureactivity relationship studies. Bioorg. Med. Chem., 2009, 17(16), 6063-6072. http://dx.doi.org/10.1016/j.bmc.2009.06.051.

[125] Candéa ALP, Ferreira ML, Pais KC et al., Synthesis and antitubercular activity of 7-chloro-4-quinolinylhydrazones derivatives. Bioorg. Med. Chem. Lett., 2009, 19(22), 6272-6274. http://dx.doi.org/10.1016/j.bmcl.2009.09.098.

[126] Upadhayaya RS, Vandavasi JK, Vasireddy NR, Sharma V, Dixit SS, Chattopadhyaya J. Design, synthesis, biological evaluation and molecular modelling studies of novel quinoline derivatives against Mycobacterium tuberculosis. Bioorg. Med. Chem., 2009, 17(11), 28302841. http://dx.doi.org/10.1016/j.bmc.2009.02.026.

[127] Nayyar A, Patel SR, Shaikh M, Coutinho E, Jain R. Synthesis, anti-tuberculosis activity and 3D-QSAR study of amino acid conjugates of 4(adamantan-1-yl) group containing quinolines. Eur. J. Med. Chem., 2009, 44(5), 2017-2029. http://dx.doi.org/10.1016/j.ejmech.2008.10.004.

[128] Lilienkampf A, Mao J, Wan B, Wang Y, Franzblau SG, Kozikowski AP. Structure-Activity Relationships for a Series of Quinoline-Based Compounds Active against Replicating and Nonreplicating Mycobacterium tuberculosis. J. Med. Chem., 2009, 52(7), 2109-2118. http://dx.doi.org/10.1021/jm900003c.

[129] Mao J, Yuan H, Wang Y et al., From Serendipity to Rational Antituberculosis Drug Discovery of Mefloquine-Isoxazole Carboxylic Acid Esters. J. Med. Chem., 2009, 52(22), 6966-6978. http://dx.doi.org/10.1021/jm900340a.

[130] Carta A, Loriga M, Paglietti G et al., Synthesis, anti-mycobacterial, antitrichomonas and anti-candida in vitro activities of 2-substituted-6,7difluoro-3- methylquinoxaline 1,4-dioxides. Eur. J. Med. Chem., 2004, 39(2), 195-203. http://dx.doi.org/10.1016/j.ejmech.2003.11.008.

[131] Seitz LE, Suling WJ, Reynolds RC. Synthesis and antimycobacterial activity of pyrazine and quinoxaline derivatives. J. Med. Chem., 2000, 45(25), 5604-5606. http://dx.doi.org/10.1021/jm020310n.

[132] Zarranz B, Jaso A, Aldana I, Monge A. Synthesis and Antimycobacterial Activity of New Quinoxaline-2-carboxamide 1, 4-di-N-Oxide Derivatives. Bioorg. Med. Chem., 2003, 11(10), 2149-2156. http://dx.doi.org/10.1016/S0968-0896(03)00119-6.

[133] Jaso A, Zarranz B, Aldana I, Monge A. Synthesis of new 2-acetyl and 2-benzoyl quinoxaline 1,4-di-N-oxide derivatives as antiMycobacterium tuberculosis agents. Eur. J. Med. Chem., 2003, 38(9), 791-800. http://dx.doi.org/10.1016/S0223-5234(03)00137-5.

[134] Villar R, Vicente E, Solano B et al.,In vitro and in vivo antimycobacterial activities of ketone and amide derivatives of quinoxaline 1,4-di-Noxide. J. Antimicrob. Chemother. 2008, 62(3), 547-554. http://dx.doi.org/10.1093/jac/dkn214.

[135] Jaso A, Zarranz B, Aldana I, Monge A. Synthesis of New Quinoxaline-2- carboxylate 1,4-Dioxide Derivatives as Anti-Mycobacterium tuberculosis Agents. J. Med. Chem., 2005, 48(6), 2019-2025. http://dx.doi.org/10.1021/jm049952w.

[136] Vicente E, Perez-Silanes S, Lima LM et al., Selective activity against Mycobacterium tuberculosis of new quinoxaline 1,4-di-N-oxides. Bioorg. Med. Chem., 2009, 17(1), 385-389 http://dx.doi.org/10.1016/j.bmc.2008.10.086.

[137] Bertino J Jr, Fish D. The safety profile of the fluoroquinolones. Clinical Therapeutics, 2000, 22(7):798-817. http://dx.doi.org/10.1016/S01492918(00)80053-3.

[138] Pasqualoto KFM, Ferreira EI. An approach for the rational design of new antituberculosis agents. Curr. Drug Targets, 2001,2 , 427-437. http://dx.doi.org/10.2174/1389450013348227.

[139] Teodori E, Dei S, Scapecchi S, Gualtieri F. The medicinal chemistry of multidrug resistance (MDR) reversing drugs. IL Farmaco, 2002, 57, 385-415. http://dx.doi.org/10.1016/S0014-827X(02)01229-6.

[140] Frieden TR, Sterling TR, Munsiff SS, Watt CJ, Dye C. Tuberculosis. Lancet, 2003, 362, 887-899. http://dx.doi.org/10.1016/S01406736(03)14333-4

[141] Smith PG, Moss AR. Epidemiology of Tuberculosis. In: Tuberculosis: Pathogenesis, Protection, and Control. Barry Bloom (Ed.), ASM Press, Washington, D.C, 1994, 47-59. http://dx.doi.org/10.1128/9781555818357.ch4.

[142] Smith CV, Huang CC, Miczak A, Russell DG, Sacchettini JC, Honer zu Bentrup, K. Biochemical and structural studies of malate synthase from Mycobacterium tuberculosis. J Biol Chem., 2003, 278, 1735-1743. http://dx.doi.org/10.1074/jbc.M209248200.

[143] Murugasu-Oei B, Dick T. Bactericidal activity of nitrofurans against growing and dormant Mycobacterium bovis BCG. J Antimicrob Chemother, 2000, 46, 917-919. http://dx.doi.org/10.1093/jac/46.6.917. 
[144] Klemens SP, DeStefano MS, Cynamon MH. Therapy of multidrug-resistant tuberculosis: lessons from studies with mice. Antimicrob Agents Chemother, 1993, 37, 2344-2347. http://dx.doi.org/10.1128/AAC.37.11.2344.

[145] Koga T, Fukuoka T, Doi N, Harasaki T, Inoue H, Hotoda H, Kakuta M, Muramatsu Y, Yamamura N, Hoshi M, Hirota T. Activity of capuramycin analogues against Mycobacterium tuberculosis, Mycobacterium avium and Mycobacterium intracellulare in vitro and in vivo. $\mathrm{J}$ Antimicrob Chemother, 2004, 54, 755-760. http://dx.doi.org/10.1093/jac/dkh417.

[146] Manabe YC, Bishai WR. Latent Mycobacterium tuberculosis-persistence, patience, and winning by waiting. Nat Med., 2000, 6, 1327-1329. http://dx.doi.org/10.1038/82139.

[147] Khasnobis S, Escuyer VE, Chatterjee D. Emerging therapeutic targets in tuberculosis: Post genomic era. Expert Opin. Ther. Targets, 2002, 6, 21-40. http://dx.doi.org/10.1517/14728222.6.1.21.

[148] Somoskovi, A, Parsons, L. M, Salfinger, M. The molecular basis of resistance to Isoniazid, Rifampin, and Pyrazinamide in Mycobacterium tuberculosis. Respir. Res., 2001, 2, 164-168. http://dx.doi.org/10.1186/rr54.

[149] Sun Z, Zhang Y. Antituberculosis activity of certain antifungal and antihelmintic drugs. Tuber Lung Dis., 1999, 79, 319-320. http://dx.doi.org/10.1054/tuld.1999.0212.

[150] Zhang Y. The magic bullets and tuberculosis drug targets. Annu Rev Pharmacol Toxicol., 2005, 45, 529-564. http://dx.doi.org/10.1146/annurev.pharmtox.45.120403.100120. 